\title{
Circadian and Sleep Disorders in Parkinson's Disease
}

\author{
Aleksandar Videnovic, MD, MSc and \\ PD and Movement Disorders Center, Circadian Rhythms and Sleep Research Laboratory, \\ Department of Neurology, Northwestern University, 710 N Lake Shore Dr \#1106, Chicago, IL \\ 60611, Tel: +1-312-503-1819, Fax: +1-312-908-5073 \\ Dr. Diego Golombek \\ Departamento de Ciencia y Tecnología, Universidad Nacional de Quilmes, Roque S. Peña 352, \\ (1876) Bernal, Pcia de Buenos Aires, Argentina, Tel. +54-11-4365-7100, Fax +54-11-4365-7132 \\ Aleksandar Videnovic: a-videnovic@northwestern.edu; Diego Golombek: dgolombek@unq.edu.ar
}

"In this stage, the sleep becomes much disturbed. The tremulous motions of the limb occur during sleep, and augment until they awaken the patients, and frequently with much agitation and alarm."

From "An Essay on the Shaking Palsy" by James Parkinson, 1817.

\section{Introduction}

Parkinson's disease (PD) is a progressive neurodegenerative disorder affecting about 300 per 100,000 people. Motor hallmarks of the disease are tremor, rigidity, bradykinesia, and impaired balance. Non-motor symptoms, such as depression, psychiatric disorders, impairment of the sleep-wake cycle, and autonomic dysfunction, are prominent causes of disability in the PD population. The characteristic pathologic finding in PD is degeneration of dopaminergic neurons in the substantia nigra with formation of Lewy bodies (Cardoso et al. 2005). It is estimated that motor cardinal symptoms of PD emerge once approximately $60 \%$ of nigral neurons have been lost and dopaminergic striatal content reduced by $80 \%$. Degeneration of nigrostriatal dopaminergic neurons follows a distinct topographic pattern: loss of dopamine (DA) is greater in the rostral than caudal striatum, and the putamen is more severely affected than the caudate nucleus (Fahn et al. 1971). Among dopaminergic receptors, which are classified in into a D1-family (D1, D5 receptors) and a D2-family (D2, D3, D4 receptors), D1 and D2 receptors have a central role in the pathogenesis of PD. In addition to the substantia nigra, other brain areas are also affected in PD, including the locus ceruleus, dorsal motor nucleus of the vagus and the pedunculopontine nucleus (Jellinger 2003). Degeneration of these regions likely begins prior to degeneration of the substantia nigra (Braak et al. 2003), and accounts for many of the non-motor features seen in PD. The non-motor features of PD have only recently been the target of therapeutic interventions (Wulff et al. 2010), although several studies suggest that non-motor symptoms of PD may have greater impact on the quality of life measures than motor symptoms (Aarsland et al. 2005, Karlsen et al. 1999, Shulman et al. 2001). Sleep dysfunction, initially recognized by James Parkinson in his famous monograph "An Essay on the Shaking Palsy," is one of the

(C) 2012 Elsevier Inc. All rights reserved.

Correspondence to: Aleksandar Videnovic, a-videnovic@northwestern.edu.

Publisher's Disclaimer: This is a PDF file of an unedited manuscript that has been accepted for publication. As a service to our customers we are providing this early version of the manuscript. The manuscript will undergo copyediting, typesetting, and review of the resulting proof before it is published in its final citable form. Please note that during the production process errors may be discovered which could affect the content, and all legal disclaimers that apply to the journal pertain. 
most striking non-motor symptoms of PD. It is only recently that sleep disturbances in PD have received the attention of the medical and research community. In this manuscript we discuss the role of dopamine in the regulation of the sleep-wake cycle and circadian timekeeping as well as outline clinical implications of circadian and sleep dysfunction in PD.

\section{Dopamine in the circadian timing system}

The circadian system comprises three main elements: an endogenous oscillator, which in mammals is located in the hypothalamic suprachiasmatic nuclei (SCN), an entrainment agent (zeitgeber) and pathways that couple the internal clock to rhythms in physiology and behavior (Golombek and Rosenstein 2010). However, more recently this scheme has been considered a simplification of what is now known as a "circadian program", which includes a number of peripheral oscillators throughout the body, orchestrated by the SCN but autonomous in terms of their rhythmic properties (Dibner et al. 2010).

Dopaminergic neurotransmission has been implied at several levels in the circadian system, starting with the photic input pathway to the clock. In the retina, dopamine plays an important role in light adaptation (Witkovsky 2004), and also regulates the rhythmic expression of melanopsin, a photopigment of intrinsically photosensitive retinal ganglion cells which has been implied in circadian entrainment (Sakamoto et al. 2005). Dopaminergic amacrine cells in the retina express circadian rhythms in clock genes which are core components of the molecular clock, such as Per, Cry, Clock and Bmal1, which might help to anticipate changes in environmental illumination and adapt the tissue for an optimal photic response (Dorenbos et al. 2007). In addition, this monoamine, presumably acting through dopaminergic D4 receptors, modulates rhythms in retinal second messengers like cAMP, therefore interacting directly with retinal physiology and sensitivity (Jackson et al. 2011). Dopamine also affects the phase and amplitude of specific clock genes (i.e., genes that are part of the core molecular oscillator), presumably through dopaminergic D1 receptors in the retina (Ruan et al. 2008). Moreover, DA is also involved in circadian sensitivity to very low light levels in Drosophila, modulating light input to the clock (Hirsh et al. 2010).

As stated before, the mammalian circadian system comprises a central oscillator located in the SCN, as well as independent clocks throughout the central nervous system and the periphery that, although autonomous in nature, require the coordination of the central clock. In the SCN, dopaminergic D1 receptors are present in both fetuses and adults (Ishida et al. 2002, Weaver et al. 1992), albeit the phase-resetting effect of dopamine is seen only prenatally (Viswanathan et al. 1994). D1 receptors in the SCN do not mediate or modulate photic or melatonin-dependent entrainment pathways in the adult (Duffield et al. 1998).

Several lines or evidence suggest that clock genes play a role in dopaminergic metabolism. For example, the clock gene (a key element of the molecular circadian oscillator) regulates dopaminergic activity in the ventral tegmental area (VTA), and related mania-like locomotor behavior (Roybal et al. 2007). Moreover, several genes involved in dopaminergic signaling are differentially regulated in the VTA of the Clock mutant mice (that also exhibits altered circadian rhythmicity), indicating a role of this gene in DA-related transcription, at least in this brain region (Roybal et al. 2007). An increased dopaminergic function in the clock mutant mouse might be the basis for an altered cocaine-reward behavior (McClung et al. 2005). Circadian fluctuations in extracellular DA levels have also been reported in the striatum and nucleus accumbens (Castaneda et al. 2004). Promoter regions of the dopamine active transporter (DAT), D1A receptor, and tyrosine hydroxylase (TH) genes include an EBox element which is the target of the canonical molecular clock. Conversely, DA (acting through D1 and D2 receptors) regulates clock gene expression in the dorsal striatum (Hood 
et al. 2010, Imbesi et al. 2009). Administration of haloperidol has been found to increase expression levels of clock genes involved in the transcriptional feedback loop responsible for circadian rhythms, both in vivo and in cultured SCN cells (Viyoch et al. 2005).

Additional evidence for the role of DA in the circadian timing system comes from neurochemical lesions with 6-hydroxydopamine injection, which disrupt normal circadian patterns of behavior and expression of Per2 (another core clock gene)(Gravotta et al. 2011); these alterations can be partially reversed by L-DOPA administration (Boulamery et al. 2010).

Dopaminergic activity and metabolism can also be considered an output of the circadian clock. Indeed, rhythmic dopaminergic neurotransmission has been described in several regions of the brain, including mesolimbic structures. For example, DA and its related metabolites and receptors exhibit daily fluctuations in their levels in different brain regions (Kafka et al. 1986). In particular, dopamine metabolism exhibits a diurnal rhythm in striatal regions, related to cyclic variations in the expression of DAT, DA receptors and TH (McClung 2007). SCN lesions have demonstrated that this structure is at least partially responsible for normal day/night differences in DAT and TH protein expression in the nucleus accumbens, medial prefrontal cortex (mPFC), and caudate (Sleipness et al. 2007), as well as for the day/night variation in cocaine-seeking behavior in rats (Sleipness et al. 2007). There is a clear interaction between dopamine and melatonin, a well-known circadian output which acts as a marker for both daily and seasonal variations in physiology and behavior, in several areas of the central nervous system (Zisapel 2001). It is also interesting that seasonal variations of DA have also been described in humans, although its importance and consequences remain to be established (Eisenberg et al. 2010).

As has already been mentioned, there are rhythms and clocks outside the SCN-related circadian behavior. Non-SCN oscillators have been implied, among many other functions, in the modulation of reward pathways. The activation of a food-entrainable oscillator, whose location is unknown and which persists even in the absence of the SCN, correlated with an increase in DA content in the forebrain (Mendoza et al. 2010). Restricted food access and reward-related behavior are associated with daily DA rhythms and vice-versa (Webb et al. 2009). It is possible that the main circadian roles of DA are therefore related not to SCNdriven circadian rhythms but to peripheral oscillators' control of reward-driven activity.

In summary, DA exhibits a two-way interaction with the circadian system at several levels. It has been hypothesized that diurnal and circadian changes in dopaminergic neurotransmission influence mood-related behavior (Hampp and Albrecht 2008) as well as addiction-related behavior (Hampp et al. 2008, McClung 2007).

\section{Dopamine involvement in the regulation of the sleep-wake cycle}

Dopamine has been traditionally associated with wake-promoting activity (Boutrel and Koob 2004, Isaac and Berridge 2003, Murillo-Rodriguez et al. 2009, Wisor et al. 2001), although it might also trigger rebound hypersomnolence (Gruner et al. 2009).

Amphetamines promote wakefulness by enhancing DA release and preventing its reuptake by DA transporter, which further illustrates wake-promoting effects of DA (Wisor et al. 2001). Current use of modafinil as a wakefulness inducer has also been linked to dopaminergic activity (Qu et al. 2008, Volkow et al. 2009).

In animal models of PD, lesions with 1-methyl-4-phenyl-1,2,3,6-tetrahydropyridine (MPTP) have been associated with reduced wakefulness (Monaca et al. 2004), disrupted sleep and circadian rhythms (Barraud et al. 2009). Similar to patients with PD, a narcolepsy-like phenotype occurs in MPTP-induced parkinsonism in non-human primates (Daley et al. 
1999). MPTP-induced parkinsonism is associated with not only sleep disruption but also alterations in other circadian rhythms in physiology and behavior, suggesting a general disturbance of the circadian system (Almirall et al. 2001, Barcia et al. 2003, Barcia et al. 2004). Studies in rodents indicate a change in sleep efficiency and architecture (specifically, reductions in REM sleep) (Laloux et al. 2008, Lima et al. 2007, Monaca et al. 2004). Similar REM sleep reduction was observed in cats (Pungor et al. 1990). Destruction of dopaminergic neurons in the ventral tegmental area, substantia nigra and periaqueductal gray neurons in rats results in diminished wakefulness ad increased REM sleep (Decker et al. 2002). However, since rodent sleep is ultradian and tends to consolidate in nocturnal bouts, non-human primate models are more suitable for this kind of research (Almirall et al. 1999, Barraud et al. 2009, Fox and Brotchie 2010, Rye 2010). Among the primate models, the marmoset MPTP model has been especially valuable in the study of motor deficits and sleep disruption, because of its interesting similarity with human sleep patterns (van Vliet et al. 2006, Verhave et al. 2011).

An additional approach to assess the role of the dopaminergic system is to study sleep and circadian rhythms in animals genetically modified to lack specific DA receptors. Although several such dopamine receptor knockouts have been produced and characterized, it is surprising that there is scarce information regarding their sleep and circadian patterns. D2knockout mice exhibit a decrease in wakefulness, which is compensated by an increase in both REM and non-REM sleep (Qu et al. 2010). D2 receptors are also involved in cataplexy in a mouse model of narcolepsy (Burgess et al. 2010) and in modulation of REM sleep in mice (Dzirasa et al. 2006). Circadian studies have focused on the role of D4 receptors in retinal entrainment pathways (Jackson et al. 2011), or masking mechanisms related to D2 receptors (Doi et al. 2006). Indeed, available knockout models are promising tools for the study of subtle modulations of the circadian system.

Mesocorticolimbic dopamine circuits are involved in promoting wakefulness and can be traced as the origin of sleep-related disturbances in Parkinson's disease (Garcia-Borreguero et al. 2003, Mehta et al. 2008, Rye 2004). Dopaminergic cells originating in the VTA and substantia nigra interact with diverse brain structures implied in the regulation of the sleepwake cycle, including the raphe nuclei, the locus coeruleus, the hypothalamus, the basal forebrain and the thalamus. These structures exhibit an increase of electrical activity in dopaminergic neurons during wakefulness, accompanied by an enhanced release of the neurotransmitter (Monti and Monti 2007). The pharmacology of dopaminergic sleep regulation is not completely clear, with D1 agonist A68930 (0.003-0.3 mg/kg) exerting a wake-promoting effect and D2-related neurotransmission inducing differential responses depending on the dose of the agonists or antagonists (Monti and Jantos 2008). Stimulation of D3 receptors with low-dose agonist pramipexole $(30 \mu \mathrm{g} / \mathrm{kg})$ results in increased slow wave sleep and decreased wakefulness; opposite effects are seen with higher doses (Monti et al. 1988). Patients exposed to dopamine agonists, however, experience excessive daytime somnolence and sudden onset sleep. Although DA participates in both wakefulness maintenance and locomotor inhibition during sleep, the exact structures and mechanisms implied in both mechanisms are not completely understood (Rye 2004). Circadian perception of environmental signals, in particular the light-dark cycle, is a key modulator of the sleep-wake cycle, and DA might also play a role in this modulation (Gonzalez and Aston-Jones 2008, Shang et al. 2011).

\section{Sleep and Alertness in PD - Clinical Implications}

A study of sleep and alertness in neurodegenerative disorders, including PD, is very challenging. The PD population is quite heterogeneous in regard to the disease onset, severity and duration as well as the presence of impaired cognition, anxiety, depression, and 
complex medication regimens. All these are significant contributors to poor overnight seep and/or daytime somnolence (Figure 1). Sleep dysfunction remains under-diagnosed by clinicians and under-reported by patients. Sleep disturbances in PD may be classified into two broad categories: disorders of nocturnal sleep and daytime alertness.

\section{Disorders of nocturnal sleep in PD}

Nighttime sleep disturbances are common in PD, affecting up to 90\% of PD patients (Factor et al. 1990, Lees et al. 1988, Tandberg et al. 1998). The most common sleep disorders in PD include insomnia, REM sleep behavior disorder, sleep apnea, and restless legs syndrome/ periodic limb movement disorder (RLS/PLMD) (Comella 2003).

\section{Insomnia}

Insomnia symptoms are the most common sleep disturbances in PD patients (Factor et al. 1990). Among them, poor sleep maintenance remains the most prevalent problem. The etiology of insomnia symptoms in PD is multifactorial and includes overnight emergence of motor symptoms, pain, nocturia, as well as the coexistence of other sleep disorders, such as sleep disordered breathing and PLMD. Tremor, rigidity and dyskinesias may emerge after an arousal and subsequently result in prolonged awakenings and inability to fall back to sleep (van Hilten et al. 1994). Nocturia is a very common complaint affecting up to $80 \%$ of PD patients (Lees et al. 1988). The frequency of nocturia increases with PD severity and duration. Depression is common in PD, and may further contribute to sleep disturbances. Depression scores in PD correlate with sleep initiation and maintenance difficulties (Happe et al. 2001). Another common cause of fragmented sleep in PD is the presence of nocturnal hallucinations, which affect almost $20 \%$ of patients. They are usually provoked by PD medications but can occur as a result of infection, use of sedatives, or electrolyte imbalance. Hallucinations are more common in advanced disease and in patients with underlying cognitive impairment. Although frequent nocturnal awakenings may have significant impact on daytime alertness, surprisingly, published data failed to demonstrate a direct correlation between poor nocturnal sleep and excessive daytime somnolence (EDS) in PD (Arnulf et al. 2002, Roth et al. 2003, Rye et al. 2000).

Improved control of nighttime motor symptoms of PD may result in improved sleep quality. Possible approaches include: the use of a long acting formulation of levodopa at bedtime; the addition of a cathechol-O-methyltransferase (COMT) inhibitor to the nighttime levodopa dose; the use of a long-acting dopamine agonist, such as carbegoline (not available in the US for PD indication); or use of an additional dose of levodopa in the middle of the night (King 1993, Pahwa et al. 1993, Pastor and Tolosa 2003, Van den Kerchove et al. 1993). Based on clinical observations, selegiline and amantidine, if taken later in the day may have primary alerting effects, and therefore delay sleep onset. These medications should be taken earlier in the day. In order to minimize nocturia patients should be advised to minimize evening fluid intake, to use the bathroom before going to the bed, and to use a bedside commode during the night. Diuretic medications should be scheduled earlier in the day. Although anticholinergic medications have not been systematically studied for the control of bladder symptoms in the PD population, it is reasonable to consider their use if the above described strategies fail to improve nocturia. If nocturia persists an evaluation by urologist is warranted. Identification and proper treatment of psychiatric comorbidities, such as depression and psychosis, may help in the consolidation of the sleep-wake cycle, but this topic is beyond the scope of this review. Similarly, an emphasis should be placed on timely diagnosis of primary sleep disorders leading to sleep fragmentation, in particular sleep disordered breathing. 


\section{REM Sleep Behavior Disorder}

REM sleep behavior disorder (RBD) is a parasomnia, first described by Schenck and colleagues in 1986 (Schenck et al. 1986). RBD is characterized by loss of muscle atonia during REM sleep as well as dream enactment behaviors. Loss of muscle atonia that normally accompanies REM sleep, allows people affected by RBD to "act out" their dreams. This may lead to serious injuries to patients and their bed partners. Some patients may have polysomnographic evidence of REM sleep without atonia (RWA) without abnormal behaviors. RWA has been referred to as "subclinical" RBD (Gagnon et al. 2002).

It is estimated that the overall prevalence of RBD is $0.5 \%$ in the general population (AASM 2005, Ohayon et al. 1997). RBD may be idiopathic or associated with a concomitant neurologic or psychiatric disease. The reported prevalence of RBD in the PD population varies from 15-60\% (Comella et al. 1998, Gagnon et al. 2002, Scaglione et al. 2005), with the variability being a result of different methods of patients selection and disorder ascertainment. In an unselected cohort of 475 sleep-disturbed patients with PD, the frequency of RBD was 46\% (Sixel-Doring et al. 2011). RBD may precede development of motor symptoms of PD and other synucleinopathies by years or decades in 18-22\% of patients (Claassen et al. 2010, Iranzo et al. 2005). In a group of 29 men with idiopathic RBD, 38\% developed parkinsonism after 5 years of follow-up, with further increase up to $65 \%$ after seven years of follow-up (Schenck et al. 1996). Estimated 5-year risk for development of a neurodegenerative disorder in idiopathic RBD is $18 \%$. This risk increases with time to $40 \%$ at 10 years and 52\% at 12 years (Postuma et al. 2009). The relationship between RBD and PD can be explained by the early involvement of the lower brainstem in PD neurodegenerative process (Braak et al. 2003). This may explain why RBD may be present prior to the development of motor symptoms of PD. RBD is not specific to idiopathic PD and can be seen in other synucleopathies, like multiple systems atrophy and Lewy body dementia (Ferman et al. 1999, Iranzo et al. 2005, Olson et al. 2000, Plazzi et al. 1997, Tachibana et al. 1997), as well as in tauopaties (progressive supranuclear palsy, Alzheimer's disease, corticobasal degeneration) though much less frequently (Olson et al. 2000, Schenck et al. 1997, Wetter et al. 2002).

The pathophysiology of idiopathic RBD in PD is not fully understood. Neurodegenerative process affecting the brainstem cholinergic, serotonergic or noradrenergic regions, such as pedunculopontine and subcoeruleal regions, may be responsible for RBD.

Neuropathological examination of the brainstem nuclei in patients with RBD reveals neuronal loss, depigmentation, gliosis and Lewy bodies in locus coeruleus-subcoeruleus complex and the substantia nigra (Fukutake et al. 2002, Kimura et al. 2000, Plazzi et al. 1997, Schenck and Mahowald 1992, Syed et al. 2003, Zambelis et al. 2002). It is likely that there are two independent anatomical systems involved in RBD. One system is responsible for the generation of muscle atonia during REM sleep, and the second for the emergence of complex behaviors of RBD. Boeve and colleagues recently proposed a mechanism leading to REM sleep atonia in humans (Boeve et al. 2007). According to this hypothesis a "direct" pathway leading to REM sleep atonia involves sublaterodorsal nucleus (or its analogous nucleus in humans) and its projections to spinal interneurons. The "indirect" contributing pathway conducts inputs from magnocellular reticular formation to spinal interneurons. The location and connections of "locomotor generators" which are responsible for complex behaviors in RBD have not been fully elucidated. Imaging studies further support the link between RBD and PD. IPT-SPECT imaging reveals a progressive reduction of striatal dopamine transporters along the continuum of normal controls, subclinical RBD, clinically manifested RBD, and PD (Eisensehr et al. 2000, Eisensehr et al. 2003), suggesting that reduced striatal dopamine transporters may be a pathophysiological mechanism of RBD. Finally, important causes or exacerbating factors of RBD are medications. RBD has been 
most commonly associated with the use of antidepressants, cholinesterase inhibitors, betablockers, tramadol, and caffeine (Mahowald and Schenck 2005). RBD may also be provoked by withdrawal from $\mathrm{ETOH}$, benzodiazepines, and barbiturates.

Clinical symptoms of RBD include dream enactment behavior manifested as motor behaviors and vocalizations. These symptoms may vary in frequency and intensity across multiple nights. Vocalizations may be brief and un-interpretable, or present as a well articulated speech. In addition, symptoms may remit for weeks or months with subsequent re-emergence. In a recent review of 231 RBD patients, the most characteristic motor and vocal behaviors included kicking, hitting, punching, jumping, screaming, talking, crying, laughing and singing (Iranzo et al. 2009). Dreams almost always have a negative emotional content, and frequently involve some form of aggression (Ferini-Strambi et al. 2005). Symptoms are more prominent in the early morning hours when the majority of REM sleep occurs. The intensity of RBD manifestations often decreases as the neurodegenerative disease progresses (Schenck and Mahowald 2002). In a study of 36 patients with PD, those with concomitant RBD had more prominent tremor, a higher frequency of falls and a lesser response to their medication (Postuma et al. 2008). The coexistence of RBD and PD is associated with a threefold increased risk of hallucinations or delusions. Up to 50\% of PD patients with RBD have hallucinations (Pacchetti et al. 2005).

The initial step in the diagnosis of RBD is a detailed sleep history obtained from patient's bed partner. Accurate and timely diagnosis of RBD and appropriate therapy are essential, as RBD symptoms can lead to serious injuries due to violent behavior both for the patient and the bed partner (Olson et al. 2000). Although a high suspicion for RBD may be established by clinical interview, up to a half of patients with RBD may not be identified using this method (Fantini et al. 2005). Further, confusional arousals and sleep disordered breathing may be associated with behaviors undistinguishable from those seen in RBD. Therefore, polysomnography is necessary for the diagnosis of RBD. Polysomnographic features of the disorder include loss of generalized muscle atonia, excessive chin muscle tone and muscle twitching during REM sleep.

Initial management of RBD should focus on safety and protective measures. Sleeping environment should be free of any potentially injurious objects, and furniture arranged to maximize safety in case of prominent dream-enactment behaviors. Detailed review of the medication regimen is mandatory, since tricyclic antidepressants, serotonin and norepinephrine reuptake inhibitors may induce RBD symptoms. Clonazepam, melatonin, or the combination of thereof are most commonly used pharmacological treatments.

Clonazepam $(0.25-1 \mathrm{mg}$ at bedtime) may be the most effective, but also associated with the development of daytime somnolence (Ozekmekci et al. 2005, Schenck and Mahowald 2005). In a small double-blind clinical trial, melatonin was reported to be effective at dose range of 3-15 mg at bedtime (Kunz and Bes 1999). Donepezil and rivastigmine have also been reported effective though the experience is limited (Aurora et al. 2010, Ringman and Simmons 2000). While few case series reported benefits with pramipexole, a double-blind trial in patients with coexistent PD and RBD found it ineffective (Fantini et al. 2003, Iranzo et al. 2005, Olson et al. 2000). Spouses should be counseled on the nature of RBD and selfprotective measures in the medication refractory cases.

Longitudinal studies of large cohort of patients with RBD are necessary in order to better understand the natural course of the disease and its association with other neurodegenerative diseases, as well as to establish effective therapeutic modalities. 


\section{Restless Legs Syndrome / Periodic Limb Movement Disorder}

Restless legs syndrome (RLS) was initially described by Ekbom in 1945 (Ekbom 1950). Estimated prevalence of RLS in general population is 2.5-10\% (Garcia-Borreguero et al. 2006). Main clinical features of RLS are an irresistible urge to move the legs, usually accompanied by an unpleasant sensation, with worsening in the evening hours and with inactivity, and improvement with movement. Patients suffering from RLS describe unpleasant sensations as a "burning", "itching", "crawling" or "feeling worms under the skin". Urge to move is prompted by these sensations. Symptoms are mainly present in lower extremities, but some patients may have symptoms in the upper limbs as well. The symptoms significantly interfere with sleep, mainly sleep initiation. Reported prevalence of RLS in the PD population vary widely between 8 and 50\% (Adler and Thorpy 2005, BragaNeto et al. 2004, Krishnan et al. 2003, Kumar et al. 2002, Nomura et al. 2006, Ondo et al. 2002, Tan et al. 2002). In a large cross-sectional epidemiological study of 23,119 US male participants of the Health Professional Follow-up Study, men with RLS had approximately threefold higher prevalence of PD than those without RLS. Exclusion of women and inability to rule-out RLS-like conditions limit the interpretation of this observation (Gao et al. 2010). Although most studies report an association between RLS and PD, the number of patients studied and the different methodologies used do not allow more definitive conclusions. The etiology of RLS remains unknown. Some functional imaging data and the high sensitivity of RLS symptoms to dopaminergic therapy point to the involvement of dopaminergic pathways (Ruottinen et al. 2000, Turjanski et al. 1999). RLS is not a preclinical form of PD, and the pathophysiological mechanisms in RLS and PD are different (Adler and Thorpy 2005). Similarly, imaging studies reveal distinct findings in these two disorders. Presynaptic dopamine transporter density is normal in RLS and reduced in PD (Eisensehr et al. 2001). Iron content in the substantia nigra is reduced in RLS patients and increased in PD patients, which has been further supported by brain parenchymal ultrasound (Allen et al. 2001, Godau et al. 2007, Schmidauer et al. 2005). Periodic limb movement disorder (PLMD), initially described by Lugaresi in 1967 as nocturnal myoclonus (Lugaresi et al. 1967), is manifested by involuntary, periodic leg and hip flexion movements. PLMD may coexist with RLS, or occur independently. It is present in 30-80\% of PD patients (Poewe and Hogl 2004), and may be more common in advanced PD (Wetter et al. 2000, Young et al. 2002).

The diagnosis of RLS is based on the four main clinical features described above (Allen et al. 2003). Polysomnography is not needed for the confirmation of RLS but can establish presence of PLMD. Secondary causes of RLS, such as renal failure, iron deficiency, hormonal alterations and neuropathies should be considered and ruled out. Akathisia, an inability to sit still due to the feeling of inner restlessness, is very common in PD. Patients with akathisia may have complaints similar to RLS, and therefore it is important to distinguish these two entities. The presence of diurnal variation of symptoms in RLS, and the feeling of inner restlessness without a sensory component in akathisia may help to differentiate between akathisia and RLS (Walters et al. 1991).

Treatment of RLS in PD has not been evaluated in controlled studies. Dopamine agonists (ropinirole, pramipexole) should be the first line therapy of RLS/PLMD in PD. Levodopa use for RLS should be avoided due to the risk of rebound and augmentation, which represent the worsening of the evening symptoms after the initiation of treatment, and their occurrence earlier during the day. Other pharmacological approaches include clonazepam, anticonvulsants medications like gabapentin, and opioids. Gabapentin enacarbil has been recently approved for the treatment of moderate-to-severe primary RLS in adults. Tricyclic and SSRI antidepressants can worsen RLS and PLMD. 


\section{Sleep disordered breathing}

Sleep disordered breathing has not been extensively studied in the PD population. Initial reports of irregular respiratory patterns with nocturnal worsening and central hypoventilation were observed in patients with post-encephalitic parkinsonism (Strieder et al. 1967, Turner and Critchley 1925).

Obstructive sleep apnea (OSA) is the most common type of sleep disordered breathing. Several studies reported the higher prevalence of OSA in PD than in general population (Arnulf et al. 2002, Diederich et al. 2005, Norlinah et al. 2009). A few recent studies, however, documented similar rates of OSA in the PD population relative to controls, suggesting that OSA may not be of a specific significance in the PD population (Cochen De Cock et al. 2010, Happe et al. 2001, Trotti and Bliwise 2010, Wetter et al. 2000).

Differences in results across these studies may be influenced by age of study participants, and/or reflect referral biases and methodologies used to ascertain the disorder. While OSA is the most common form of sleep apnea syndrome in the general population, obstructive, central and mixed apneas may be equally represented in PD patients (Diederich et al. 2005). Obesity is a strong predictor of OSA in the general population (Schafer et al. 2002). Of interest is that most PD patients with OSA have normal body mass indices. There is no clear relationship between the prevalence of OSA in PD and disease duration, severity, or PD medication regimen (Ferini-Strambi et al. 1992, Maria et al. 2003, Wetter et al. 2000).

A detailed general medical and sleep history is necessary for the establishing of the proper diagnosis of sleep disordered breathing. History should be obtained from both the patient and his/her bed partner. Specific questioning about snoring, choking, shortness of breath, early morning headaches and daytime sleepiness should be done. Polysomnography is used to confirm the diagnosis and to assess its severity.

Continuous positive airway pressure (CPAP) is the treatment of choice for OSA, but has not been systematically studied in the PD population. CPAP has been successfully utilized by patients affected by other neurodegenerative disorders, including Alzheimer's disease; it is therefore likely that PD patients would be able to tolerate it as well. Like in general population, this therapy may be difficult to implement in a proportion of PD patients, due to the comfort issues. Other factors that may interfere with CPAP use are nasal obstruction, sinus infection, chronic mouth breathing and lack of motivation. Several surgical approaches (uvulopalatopharyngoplasty, removal of enlarged tonsils and adenoids, advancement of the mandible) are available for patients who cannot tolerate CPAP. Several orthodontic appliances are available for the use as well.

\section{Disorders of daytime alertness in PD}

Excessive daytime somnolence (EDS) affects up to 50\% of PD patients. The incidence of EDS increases with the progression of the disease. While EDS has long been recognized in PD, it has not received medical attention until the entity of "sleep attack" was reported, described as sudden onset sleep in PD patients treated with pramipexole or ropinirole (Frucht et al. 1999). Frucht and colleagues defined sleep attacks as "events of overwhelming sleepiness that occur without warning or with a prodrome that is sufficiently short or overpowering to prevent the patient from taking appropriate protective measures". In a survey of 2,952 PD patients, 6\% had sleep attacks (Paus et al. 2003). Some studies report the prevalence of sleep attacks in PD as high as 32\% and 43\% (Korner et al. 2004, Manni et al. 2004, Montastruc et al. 2001). EDS and sleep attacks pose significant safety risks and may lead to motor vehicle accidents. Based on the survey of 638 highly functioning PD patients, 420 of whom were drivers, $3.8 \%$ patients had at least one episode of sudden onset sleep while driving, and $0.7 \%$ had no warning (Hobson et al. 2002). Others have reported an even 
higher incidence of falling asleep while driving, up to $22.6 \%$ of studied PD subjects (Ondo et al. 2001).

The etiology of EDS in PD is multifactorial. Primary neurodenerative process of PD, complex medication regimen, age-related changes in the sleep architecture, and coexistent sleep disturbances play an important role in the development of EDS. EDS is uncommon in newly diagnosed, untreated PD patients (Fabbrini et al. 2002, Kaynak et al. 2005); however, a significant number of these patients developed EDS during the first year of therapy. EDS may be one of the pre-motor PD markers and/or risk factors for development of PD (Abbott et al. 2005, Gao et al. 2011). In the Honolulu-Asia Aging Study, there was more than a three-fold increase in the risk of developing PD in elderly men with EDS that could not be accounted for by any other factor (Abbott et al. 2005). The loss of the hypothalamic wakepromoting substance, hypocretin (orexin), has been implicated in EDS associated with PD. Initial reports of significantly reduced hypocretin levels in ventricular cerebrospinal fluid (CSF) in PD (Drouot et al. 2003), are further strengthened by observations of reduced postmortem hypocretin brain tissue and CSF concentrations, as well as reduced number of hypocretin neurons in PD patients relative to controls (Fronczek et al. 2007). Thannickal and colleagues recently found increasing loss of hypocretin neurons, which appears to correlates with the clinical stage of PD (Thannickal et al. 2007). Dopaminergic medications play a significant role in impaired daytime alertness of PD patients. In major clinical trials of levodopa and dopamine agonists, somnolence was reported in 13\%-36\% of patients (PSG 2000, Rascol et al. 2000). Levodopa mono-therapy confers the lowest risk for sleep attacks, while combination therapy with levodopa and dopamine agonist presents the highest risk (Paus et al. 2003). Sleep disorders such as sleep apnea, periodic limb movements during sleep (PLMD) and sleep fragmentation are frequent in PD, and may contribute to daytime sleepiness. Although, it has been postulated that nocturnal sleep deprivation may contribute to EDS, several reports using objective assessments of sleep and alertness failed to conform this association (Arnulf et al. 2002, Rye 2004). Other significant causes of EDS in PD are cognitive dysfunction and depression.

A detailed medical history with special emphasis on the sleep history, including collateral information for the spouse/caregiver, is an initial step in the evaluation of EDS. Careful review of the medication regimen, other co-morbidities, alcohol and caffeine intake can identify these important contributing factors in the development of EDS. Patients should be screened for co-existent sleep disorders as well.

Several objective and subjective diagnostic tools have been used for the diagnosis of EDS in PD patients. Although the Multiple Sleep Latency Test (MSLT) remains the gold standard for the diagnosis of EDS (Arnulf et al. 2002, Fabbrini et al. 2002, Gjerstad et al. 2002), it is expensive, time consuming and, therefore, not practical for the screening purposes. The Maintenance of Wakefulness Test (MWT), frequently used to assess treatment responses following interventions for excessive sleepiness, has been less studied and may not correlate well with the MSLT in the PD population affected by EDS (Stevens et al. 2004). The Epworth Sleepiness Scale (ESS) was validated in the PD population, however, the validity of the scale to adequately quantify EDS remains controversial. Up to 4\% of PD patients who report ESS score > 15 do not appreciate daytime somnolence (Brodsky et al. 2003). Others reported a strong correlation between sudden onset sleep and ESS sore (Korner et al. 2004). Overall, ESS is considered to be a useful and easily administered screening tool for EDS. The Parkinson's Disease Sleep Scale (PDSS) is a validated instrument designed to evaluate quality of sleep in PD (Chaudhuri et al. 2002). The scale has been recently revised (PDSS-2) in order to capture several previously unmet needs in evaluating certain sleep disturbances in PD (e.g., nocturnal RLS, akinesia, pain, sleep apnea) (Trenkwalder et al. 2011). The revised PDSS-2 consists of 15 questions which are to be rated by the patients using one of five 
categories, from 0 (never) to 4 (very frequent). PDSS-2 total score ranges from 0 (no disturbance) to 60 (maximum nocturnal disturbance). The SCOPA-SLEEP is another instrument specifically designed to asses sleep disturbances in the PD population (Marinus et al. 2003). It consists of two subscales that address daytime sleepiness and nighttime sleep, and an additional question which evaluates overall sleep quality on a 7-point scale. The scale correlates well with the Pittsburg Sleep Quality Index and the ESS (Marinus et al. 2003).

Treatment of EDS in PD is challenging. Patients' education about healthy sleep hygiene is the initial step in the management of EDS. A suspicion of a co-existent sleep disorder should prompt a consultation with a sleep specialist. Detailed review of the medication regimen is essential. Medications with soporific profile should be minimized/discontinued, and those with an activating profile (e.g. selegiline or amantadine) given earlier in the day. The dose of dopaminergic medications may need to be reduced, and the class of dopaminergic agents may need to be substituted for a different one (specifically DA). Patients who experience sudden onset sleep/sleep attacks should be advised not to drive until the issue is resolved.

If the above discussed strategies do not improve EDS, the use of stimulants and wakepromoting agents should be considered. Stimulant medications, such as dextroamphetamine, metamphetamine and methylphenidate have been used for the treatment of EDS with variable success (Chokroverty and Rye 2003). Amphetamines, however, have addictive properties, can cause disruption of nocturnal sleep, adverse cardiovascular events, and therefore are rarely used for the treatment of sleepiness in PD population.

Modafinil is a novel wake-promoting agent whose mechanism of action has not been fully understood. Modafinil has been evaluated in open-label and controlled trials for the treatment of EDS in PD. While some trials demonstrate improvement in daytime somnolence with daily doses of 100-200mg/day (Adler et al. 2003, Hogl et al. 2002), others did not find any beneficial effects (Ondo et al. 2005)..

Melatonin, a neurohormone produced by the pineal gland, has been shown to decrease sleep initiation difficulties and nighttime activity in older adults (Garfinkel et al. 1997, MacFarlane et al. 1991). In a recent study of 40 PD patients with disturbed sleep, administration of $5 \mathrm{mg}$ or $50 \mathrm{mg}$ of melatonin daily for two weeks, resulted in similar improvements in subjective sleep disturbance, sleep quality and daytime sleepiness (Dowling et al. 2005). Ramelteon (Rozerem), a new hypnotic agent approved for sleep initiation insomnia, which has a novel mechanism of action via melatonin receptors, may be beneficial in PD but has not been formally studied.

Deep brain stimulation (DBS) has become an important treatment option for PD patients with disabling motor complications and dyskinesias. Several authors reported an improvement in nocturnal sleep in PD patients who underwent DBS (Antonini et al. 2004, Cicolin et al. 2004, Hjort et al. 2004). The impact of DBS on EDS however has not been systematically studied.

\section{Circadian rhythm dysfunction in PD}

Changes in circadian rhythmicity have been associated with reduced nighttime sleep quality, daytime alertness and cognitive performance (Buysse et al. 2005, Silva et al. 2010, van den Heuvel and Lushington 2002, Waterhouse 2010). Age-related changes in the circadian timing system have been associated with reduced amplitude of some circadian rhythms, and increased inter-daily variability (decreased stability) of a rhythm, such as the rest-activity cycle (Czeisler et al. 1992, Duffy et al. 2002, Hofman 2000, Touitou and Haus 2000, Turek et al. 1995, van Coevorden et al. 1991). The timing of physiological rhythms may be altered, leading to changes in the phase relationship of rhythms to each other, which can cause 
internal desynchronization. This loss of coordination of rhythms may have negative consequences on rest-activity cycles and other physiological and behavioral functions (Harper et al. 2005, Reinberg and Ashkenazi 2008, Reinberg et al. 1985). Despite this knowledge and frequent occurrence of disrupted sleep and alertness in the PD population, circadian rhythms have not been systematically studied in PD.

Daily clinical fluctuations of symptoms and signs associated with PD have been well recognized. These include changes in daily motor activity (Bonuccelli et al. 2000, Nutt et al. 1989, van Hilten et al. 1993, van Hilten et al. 1991), autonomic function (Arias-Vera et al. 2003, Devos et al. 2003, Ejaz et al. 2006, Mihci et al. 2006, Pathak and Senard 2006, Pursiainen et al. 2002), sleep-wake cycles (Comella 2007, Placidi et al. 2008, Porter et al. 2008, van Hilten et al. 1993, Verbaan et al. 2008), visual performance (Struck et al. 1990), as well as responsiveness to dopaminergic treatments (Bonuccelli et al. 2000, Piccini et al. 1991). These observations may be suggestive of modifications in circadian rhythmicity in PD. Actigraphy studies in PD patients demonstrate lower peak activity levels and lower amplitude of the rest-activity cycle compared to healthy older adults (van Hilten et al. 1993, van Hilten et al. 1991, Whitehead et al. 2008). Increased levels of physical activity and shorter periods of immobility during the night, result in an almost flat diurnal pattern of motor activity in PD (van Hilten et al. 1994, van Hilten et al. 1993). In addition, PD patients have a more fragmented pattern of activity with transitions from high to low activity periods, leading to less predictable rest-activity rhythm (Whitehead et al. 2008). Motor symptoms in PD worsen in the afternoon and evening, both in stable patients and in those with wearing off symptoms (Bonuccelli et al. 2000, Piccini et al. 1991). Furthermore, responsiveness of PD motor symptoms to dopaminergic treatments declines throughout the day, despite the absence of significant changes in levodopa pharmacokinetics (Bonuccelli et al. 2000). Alterations in the circadian regulation of the autonomic system in PD have also been reported. Twenty-four hour ambulatory blood pressure monitoring in patients with PD demonstrates reversal of circadian rhythm of blood pressure, increased diurnal blood pressure variability, postprandial hypotension, and a high nocturnal blood pressure (Ejaz et al. 2006, Kallio et al. 2000, Plaschke et al. 1998, Senard et al. 1992). Holter electrocardiographic monitoring reveals a decrease of sympathetic activity during the day with a loss of the circadian heart rate variability and a disappearance of the sympathetic morning peak (Devos et al. 2003). Similarly to motor performance and autonomic function, circadian fluctuations of visual performance, measured by contrast sensitivity, have been reported in PD (Struck et al. 1990). Impairment of retinal dopamine, which exhibits an endogenous circadian rhythm independent of light/dark cycles, is most likely underlying these changes (Wirz-Justice et al. 1984). Since circadian changes in contrast sensitivity may occur independently of circadian oscillations in motor symptoms, it is possible that various anatomical networks (retina, striatum, cortex) may have differential threshold to the circadian signal of dopamine (Dearry and Burnside 1986).

Biological markers of the circadian system may provide insight into the function of circadian timekeeping in PD. Only a few studies attempted to characterize profiles of circadian markers in PD. In a cohort of 26 PD patients, the amplitude of melatonin rhythm was decreased, and phase was advanced in treated patients with and without motor complications compared to de novo patients (Bordet et al. 2003). These results suggest a trend toward melatonin phase advance and amplitude reduction during the evolution of PD. In a separate study, nine patients with de novo PD had a preserved melatonin rhythm compared with healthy controls (Fertl et al. 1993). In a study of 12 PD patients, 24-hour mean cortisol production rate was significantly higher and the mean secretory cortisol curve was flatter, leading to significantly reduced diurnal variation in the PD group relative to controls (Hartmann et al. 1997). While 24-hour rhythms of core body temperature remain similar in PD relative to healthy controls (Pierangeli et al. 2001), basal body temperature is 
significantly lower in parkinsonian patients (Cagnacci et al. 1990). PD patients with coexistent depression have altered circadian rhythms of rectal temperature and lower amplitudes of core body temperature (Suzuki et al. 2007). These circadian modifications of temperature regulation have been confirmed in the 6-OHDA animal model of parkinsonism where a significant decrease of the mesor and a phase advance of temperature rhythm have been reported (Ben et al. 1999). Although these investigations suggest modifications of circadian rhythmicity in $\mathrm{PD}$, results are to be interpreted with caution due to small sample sizes and study designs that reflect influences of both endogenous circadian and exogenous (e.g. light exposure, physical activity, meals, social schedules) rhythms on PD.

Mechanisms underlying circadian fluctuations of symptoms and signs of PD remain unknown. Fluctuations in dopamine metabolism, overnight dopamine accumulation or diurnal receptor downregulation may be in part driving these fluctuations (Bruinink et al. 1983, Khaldy et al. 2002, Weber et al. 2004). Neuroanatomical sites of circadian disruption in PD may be along the afferent pathways to the SCN, within the SCN itself, or within the downstream peripheral efferents of the SCN. For example, reduced light exposure and/or impaired light transmission, partly due to dopaminergic retinal degeneration (Archibald et al. 2009), may affect circadian timekeeping in the PD population. In a recent study of circadian function in alpha-synuclein over-expressing mice, no evidence for light entrainment deficits was found (Kudo et al. 2011). While the structure and function of the SCN in PD has not been rigorously examined to date, degeneration of this central circadian pacemaker may be yet another possible mechanism of impaired circadian rhythmicity in PD. Hypothalamic dopaminergic neurons, however, do not appear to be involved by the disease (Matzuk and Saper 1985). Finally, alterations in SCN output may be primarily responsible for fluctuating biological rhythms and symptoms of PD.

Light, the main synchronizer for the human circadian system, is increasingly applied in a variety of sleep and neuropsychiatric conditions including circadian rhythm disorders, seasonal affective disorder, and dementia (Shirani and St Louis 2009). Dopamine is a likely mediator of light signaling to the retinal circadian clock which provides direct input to the SCN (Witkovsky 2004). Exposure to light facilitates recovery of motor function in a chronic experimental model of PD (Harrell and Balagura 1974). Few exploratory studies examined the effects of bright light in PD, and documented significant improvements in depression, bradykinesia, rigidity, and dyskinesias (Paus et al. 2007, Willis and Turner 2007). Further validation studies including larger cohorts and employing objective outcome measures are needed.

\section{Conclusion}

Disturbances of nocturnal sleep and daytime somnolence are common and under-recognized in patients with PD. Both have significant negative impact on the quality of life in the PD population. The majority of the therapeutic recommendations for sleep disorders in the PD population are based on open-label small patient cohort clinical trials or case reports.

Therefore, double-blind, placebo-controlled clinical trials with a large number of patients are necessary in order to establish the efficacy and safety of therapeutic interventions aimed at the treatment of sleep dysfunction in PD. Increasing evidence suggest disruptions of the circadian system in PD. Further systematic investigations directed to the circadian timekeeping may provide additional insight into the pathogenesis of daytime sleepiness and sleep dysfunction, and possibly shed new insights about the neurodegenerative process of PD itself. 


\section{References}

Aarsland D, Alves G, Larsen JP. Disorders of motivation, sexual conduct, and sleep in Parkinson's disease. Adv Neurol. 2005; 96:56-64. [PubMed: 16383212]

AASM. American Academy of Sleep Medicne. 2. Westchester, IL: 2005. The international classification of sleep disorders.

Abbott RD, Ross GW, White LR, Tanner CM, Masaki KH, Nelson JS, Curb JD, Petrovitch H. Excessive daytime sleepiness and subsequent development of Parkinson disease. Neurology. 2005; 65:1442-1446. [PubMed: 16275833]

Adler CH, Caviness JN, Hentz JG, Lind M, Tiede J. Randomized trial of modafinil for treating subjective daytime sleepiness in patients with Parkinson's disease. Mov Disord. 2003; 18:287-293. [PubMed: 12621632]

Adler CH, Thorpy MJ. Sleep issues in Parkinson's disease. Neurology. 2005; 64:S12-20. [PubMed: 15994219]

Allen RP, Barker PB, Wehrl F, Song HK, Earley CJ. MRI measurement of brain iron in patients with restless legs syndrome. Neurology. 2001; 56:263-265. [PubMed: 11160969]

Allen RP, Picchietti D, Hening WA, Trenkwalder C, Walters AS, Montplaisi J. Restless legs syndrome: diagnostic criteria, special considerations, and epidemiology. A report from the restless legs syndrome diagnosis and epidemiology workshop at the National Institutes of Health. Sleep Med. 2003; 4:101-119. [PubMed: 14592341]

Almirall H, Bautista V, Sanchez-Bahillo A, Trinidad-Herrero M. Ultradian and circadian body temperature and activity rhythms in chronic MPTP treated monkeys. Neurophysiol Clin. 2001; 31:161-170. [PubMed: 11488227]

Almirall H, Pigarev I, de la Calzada MD, Pigareva M, Herrero MT, Sagales T. Nocturnal sleep structure and temperature slope in MPTP treated monkeys. J Neural Transm. 1999; 106:1125-1134. [PubMed: 10651108]

Antonini A, Landi A, Mariani C, DeNotaris R, Pezzoli G. Deep brain stimulation and its effect on sleep in Parkinson's disease. Sleep Med. 2004; 5:211-214. [PubMed: 15033146]

Archibald NK, Clarke MP, Mosimann UP, Burn DJ. The retina in Parkinson's disease. Brain. 2009; 132:1128-1145. [PubMed: 19336464]

Arias-Vera JR, Mansoor GA, White WB. Abnormalities in blood pressure regulation in a patient with Parkinson's disease. Am J Hypertens. 2003; 16:612-613. [PubMed: 12850398]

Arnulf I, Konofal E, Merino-Andreu M, Houeto JL, Mesnage V, Welter ML, Lacomblez L, Golmard JL, Derenne JP, Agid Y. Parkinson's disease and sleepiness: an integral part of PD. Neurology. 2002; 58:1019-1024. [PubMed: 11940685]

Aurora RN, Zak RS, Maganti RK, Auerbach SH, Casey KR, Chowdhuri S, Karippot A, Ramar K, Kristo DA, Morgenthaler TI. Best practice guide for the treatment of REM sleep behavior disorder (RBD). J Clin Sleep Med. 2010; 6:85-95. [PubMed: 20191945]

Barcia C, Bautista V, Sanchez-Bahillo A, Fernandez-Villalba E, Navarro-Ruis JM, Barreiro AF, Poza YPM, Herrero MT. Circadian determinations of cortisol, prolactin and melatonin in chronic methyl-phenyl-tetrahydropyridine-treated monkeys. Neuroendocrinology. 2003; 78:118-128. [PubMed: 12915764]

Barcia C, De Pablos V, Bautista-Hernandez V, Sanchez-Bahillo A, Fernandez-Barreiro A, Poza M, Herrero MT. Measurement of motor disability in MPTP-treated macaques using a telemetry system for estimating circadian motor activity. J Neurosci Methods. 2004; 134:59-64. [PubMed: 15102503]

Barraud Q, Lambrecq V, Forni C, McGuire S, Hill M, Bioulac B, Balzamo E, Bezard E, Tison F, Ghorayeb I. Sleep disorders in Parkinson's disease: the contribution of the MPTP non-human primate model. Exp Neurol. 2009; 219:574-582. [PubMed: 19635479]

Ben V, Blin O, Bruguerolle B. Time-dependent striatal dopamine depletion after injection of 6hydroxydopamine in the rat. Comparison of single bilateral and double bilateral lesions. J Pharm Pharmacol. 1999; 51:1405-1408. [PubMed: 10678495]

Boeve BF, Silber MH, Saper CB, Ferman TJ, Dickson DW, Parisi JE, Benarroch EE, Ahlskog JE, Smith GE, Caselli RC, Tippman-Peikert M, Olson EJ, Lin SC, Young T, Wszolek Z, Schenck CH, 
Mahowald MW, Castillo PR, Del Tredici K, Braak H. Pathophysiology of REM sleep behaviour disorder and relevance to neurodegenerative disease. Brain. 2007; 130:2770-2788. [PubMed: 17412731]

Bonuccelli U, Del Dotto P, Lucetti C, Petrozzi L, Bernardini S, Gambaccini G, Rossi G, Piccini P. Diurnal motor variations to repeated doses of levodopa in Parkinson's disease. Clin Neuropharmacol. 2000; 23:28-33. [PubMed: 10682228]

Bordet R, Devos D, Brique S, Touitou Y, Guieu JD, Libersa C, Destee A. Study of circadian melatonin secretion pattern at different stages of Parkinson's disease. Clin Neuropharmacol. 2003; 26:65-72. [PubMed: 12671525]

Boulamery A, Simon N, Vidal J, Bruguerolle B. Effects of L-Dopa on circadian rhythms of 6-OHDA striatal lesioned rats: a radiotelemetric study. Chronobiol Int. 2010; 27:251-264. [PubMed: 20370468]

Boutrel B, Koob GF. What keeps us awake: the neuropharmacology of stimulants and wakefulnesspromoting medications. Sleep. 2004; 27:1181-1194. [PubMed: 15532213]

Braak H, Del Tredici K, Rub U, de Vos RA, Jansen Steur EN, Braak E. Staging of brain pathology related to sporadic Parkinson's disease. Neurobiol Aging. 2003; 24:197-211. [PubMed: 12498954]

Braga-Neto P, da Silva FP Junior, Sueli Monte F, de Bruin PF, de Bruin VM. Snoring and excessive daytime sleepiness in Parkinson's disease. J Neurol Sci. 2004; 217:41-45. [PubMed: 14675608]

Brodsky MA, Godbold J, Roth T, Olanow CW. Sleepiness in Parkinson's disease: a controlled study. Mov Disord. 2003; 18:668-672. [PubMed: 12784270]

Bruinink A, Lichtensteiger W, Schlumpf M. Ontogeny of diurnal rhythms of central dopamine, serotonin and spirodecanone binding sites and of motor activity in the rat. Life Sci. 1983; 33:3138. [PubMed: 6306372]

Burgess CR, Tse G, Gillis L, Peever JH. Dopaminergic regulation of sleep and cataplexy in a murine model of narcolepsy. Sleep. 2010; 33:1295-1304. [PubMed: 21061851]

Buysse DJ, Monk TH, Carrier J, Begley A. Circadian patterns of sleep, sleepiness, and performance in older and younger adults. Sleep. 2005; 28:1365-1376. [PubMed: 16335481]

Cagnacci A, Bonuccelli U, Melis GB, Soldani R, Piccini P, Napolitano A, Muratorio A, Fioretti P. Effect of naloxone on body temperature in postmenopausal women with Parkinson's disease. Life Sci. 1990; 46:1241-1247. [PubMed: 2338888]

Cardoso SM, Moreira PI, Agostinho P, Pereira C, Oliveira CR. Neurodegenerative pathways in Parkinson's disease: therapeutic strategies. Curr Drug Targets CNS Neurol Disord. 2005; 4:405419. [PubMed: 16101557]

Castaneda TR, de Prado BM, Prieto D, Mora F. Circadian rhythms of dopamine, glutamate and GABA in the striatum and nucleus accumbens of the awake rat: modulation by light. J Pineal Res. 2004; 36:177-185. [PubMed: 15009508]

Chaudhuri KR, Pal S, DiMarco A, Whately-Smith C, Bridgman K, Mathew R, Pezzela FR, Forbes A, Hogl B, Trenkwalder C. The Parkinson's disease sleep scale: a new instrument for assessing sleep and nocturnal disability in Parkinson's disease. J Neurol Neurosurg Psychiatry. 2002; 73:629-635. [PubMed: 12438461]

Chokroverty SS, Rye DB. Narcolepsy in the older adult: epidemiology, diagnosis and management. Drugs Aging. 2003; 20:361-376. [PubMed: 12696996]

Cicolin A, Lopiano L, Zibetti M, Torre E, Tavella A, Guastamacchia G, Terreni A, Makrydakis G, Fattori E, Lanotte MM, Bergamasco B, Mutani R. Effects of deep brain stimulation of the subthalamic nucleus on sleep architecture in parkinsonian patients. Sleep Med. 2004; 5:207-210. [PubMed: 15033145]

Claassen DO, Josephs KA, Ahlskog JE, Silber MH, Tippmann-Peikert M, Boeve BF. REM sleep behavior disorder preceding other aspects of synucleinopathies by up to half a century. Neurology. 2010; 75:494-499. [PubMed: 20668263]

Cochen De Cock V, Abouda M, Leu S, Oudiette D, Roze E, Vidailhet M, Similowski T, Arnulf I. Is obstructive sleep apnea a problem in Parkinson's disease? Sleep Med. 2010; 11:247-252. [PubMed: 19628429] 
Comella C. Sleep episodes in Parkinson's disease: more questions remain. Sleep Med. 2003; 4:267268. [PubMed: 14592295]

Comella CL. Sleep disorders in Parkinson's disease: An overview. Mov Disord. 2007; 22:S367-S373. [PubMed: 18175398]

Comella CL, Nardine TM, Diederich NJ, Stebbins GT. Sleep-related violence, injury, and REM sleep behavior disorder in Parkinson's disease. Neurology. 1998; 51:526-529. [PubMed: 9710029]

Czeisler CA, Dumont M, Duffy JF, Steinberg JD, Richardson GS, Brown EN, Sanchez R, Rios CD, Ronda JM. Association of sleep-wake habits in older people with changes in output of circadian pacemaker. Lancet. 1992; 340:933-936. [PubMed: 1357348]

Daley J, Turner R, Bliwise DL, Rye DB. Nocturnal sleep and daytime alertness in the MPTP-treated primate. Sleep. 1999; 22 (Suppl):S218-219.

Dearry A, Burnside B. Dopaminergic regulation of cone retinomotor movement in isolated teleost retinas: I. Induction of cone contraction is mediated by D2 receptors. J Neurochem. 1986; 46:1006-1021. [PubMed: 2869104]

Decker MJ, Keating G, Hue GE, Freeman A, Rye DD. Mesolimbic dopamine's modulation of REM sleep. J Sleep Res (supl). 2002; 51:51-52.

Devos D, Kroumova M, Bordet R, Vodougnon H, Guieu JD, Libersa C, Destee A. Heart rate variability and Parkinson's disease severity. J Neural Transm. 2003; 110:997-1011. [PubMed: 12928836]

Dibner C, Schibler U, Albrecht U. The mammalian circadian timing system: organization and coordination of central and peripheral clocks. Annu Rev Physiol. 2010; 72:517-549. [PubMed: 20148687]

Diederich NJ, Vaillant M, Leischen M, Mancuso G, Golinval S, Nati R, Schlesser M. Sleep apnea syndrome in Parkinson's disease. A case-control study in 49 patients. Mov Disord. 2005; 20:14131418. [PubMed: 16007620]

Diederich NJ, Vaillant M, Leischen M, Mancuso G, Golinval S, Nati R, Schlesser M. Sleep apnea syndrome in Parkinson's disease. A case-control study in 49 patients. Mov Disord. 2005; 20:14131418. [PubMed: 16007620]

Doi M, Yujnovsky I, Hirayama J, Malerba M, Tirotta E, Sassone-Corsi P, Borrelli E. Impaired light masking in dopamine D2 receptor-null mice. Nat Neurosci. 2006; 9:732-734. [PubMed: 16715079]

Dorenbos R, Contini M, Hirasawa H, Gustincich S, Raviola E. Expression of circadian clock genes in retinal dopaminergic cells. Vis Neurosci. 2007; 24:573-580. [PubMed: 17705893]

Dowling GA, Mastick J, Colling E, Carter JH, Singer CM, Aminoff MJ. Melatonin for sleep disturbances in Parkinson's disease. Sleep Med. 2005; 6:459-466. [PubMed: 16084125]

Drouot X, Moutereau S, Nguyen JP, Lefaucheur JP, Creange A, Remy P, Goldenberg F, d'Ortho MP. Low levels of ventricular CSF orexin/hypocretin in advanced PD. Neurology. 2003; 61:540-543. [PubMed: 12939433]

Duffield GE, Hastings MH, Ebling FJ. Investigation into the regulation of the circadian system by dopamine and melatonin in the adult Siberian hamster (Phodopus sungorus). J Neuroendocrinol. 1998; 10:871-884. [PubMed: 9831263]

Duffy JF, Zeitzer JM, Rimmer DW, Klerman EB, Dijk DJ, Czeisler CA. Peak of circadian melatonin rhythm occurs later within the sleep of older subjects. Am J Physiol Endocrinol Metab. 2002; 282:E297-303. [PubMed: 11788360]

Dzirasa K, Ribeiro S, Costa R, Santos LM, Lin SC, Grosmark A, Sotnikova TD, Gainetdinov RR, Caron MG, Nicolelis MA. Dopaminergic control of sleep-wake states. J Neurosci. 2006; 26:10577-10589. [PubMed: 17035544]

Eisenberg DP, Kohn PD, Baller EB, Bronstein JA, Masdeu JC, Berman KF. Seasonal effects on human striatal presynaptic dopamine synthesis. J Neurosci. 2010; 30:14691-14694. [PubMed: 21048126]

Eisensehr I, Linke R, Noachtar S, Schwarz J, Gildehaus FJ, Tatsch K. Reduced striatal dopamine transporters in idiopathic rapid eye movement sleep behaviour disorder. Comparison with Parkinson's disease and controls. Brain. 2000; 123 (Pt 6):1155-1160. [PubMed: 10825354] 
Eisensehr I, Linke R, Tatsch K, Kharraz B, Gildehaus JF, Wetter CT, Trenkwalder C, Schwarz J, Noachtar S. Increased muscle activity during rapid eye movement sleep correlates with decrease of striatal presynaptic dopamine transporters. IPT and IBZM SPECT imaging in subclinical and clinically manifest idiopathic REM sleep behavior disorder, Parkinson's disease, and controls. Sleep. 2003; 26:507-512. [PubMed: 12938802]

Eisensehr I, Wetter TC, Linke R, Noachtar S, von Lindeiner H, Gildehaus FJ, Trenkwalder C, Tatsch K. Normal IPT and IBZM SPECT in drug-naive and levodopa-treated idiopathic restless legs syndrome. Neurology. 2001; 57:1307-1309. [PubMed: 11591854]

Ejaz AA, Sekhon IS, Munjal S. Characteristic findings on 24-h ambulatory blood pressure monitoring in a series of patients with Parkinson's disease. Eur J Intern Med. 2006; 17:417-420. [PubMed: 16962949]

Ekbom KA. Restless legs; a report of 70 new cases. Acta Med Scand Suppl. 1950; 246:64-68. [PubMed: 14789493]

Fabbrini G, Barbanti P, Aurilia C, Vanacore N, Pauletti C, Meco G. Excessive daytime sleepiness in de novo and treated Parkinson's disease. Mov Disord. 2002; 17:1026-1030. [PubMed: 12360553]

Factor SA, McAlarney T, Sanchez-Ramos JR, Weiner WJ. Sleep disorders and sleep effect in Parkinson's disease. Mov Disord. 1990; 5:280-285. [PubMed: 2259351]

Fahn S, Libsch LR, Cutler RW. Monoamines in the human neostriatum: topographic distribution in normals and in Parkinson's disease and their role in akinesia, rigidity, chorea, and tremor. J Neurol Sci. 1971; 14:427-455. [PubMed: 5125758]

Fantini ML, Ferini-Strambi L, Montplaisir J. Idiopathic REM sleep behavior disorder: toward a better nosologic definition. Neurology. 2005; 64:780-786. [PubMed: 15753409]

Fantini ML, Gagnon JF, Filipini D, Montplaisir J. The effects of pramipexole in REM sleep behavior disorder. Neurology. 2003; 61:1418-1420. [PubMed: 14638967]

Ferini-Strambi L, Fantini ML, Zucconi M, Castronovo V, Marelli S, Oldani A, Cappa S. REM sleep behaviour disorder. Neurol Sci. 2005; 26(Suppl 3):s186-192. [PubMed: 16331394]

Ferini-Strambi L, Franceschi M, Pinto P, Zucconi M, Smirne S. Respiration and heart rate variability during sleep in untreated Parkinson patients. Gerontology. 1992; 38:92-98. [PubMed: 1612468]

Ferman TJ, Boeve BF, Smith GE, Silber MH, Kokmen E, Petersen RC, Ivnik RJ. REM sleep behavior disorder and dementia: cognitive differences when compared with AD. Neurology. 1999; 52:951957. [PubMed: 10102411]

Fertl E, Auff E, Doppelbauer A, Waldhauser F. Circadian secretion pattern of melatonin in de novo parkinsonian patients: evidence for phase-shifting properties of l-dopa. J Neural Transm Park Dis Dement Sect. 1993; 5:227-234. [PubMed: 8369102]

Fox SH, Brotchie JM. The MPTP-lesioned non-human primate models of Parkinson's disease. Past, present, and future. Prog Brain Res. 2010; 184:133-157. [PubMed: 20887873]

Fronczek R, Overeem S, Lee SY, Hegeman IM, van Pelt J, van Duinen SG, Lammers GJ, Swaab DF. Hypocretin (orexin) loss in Parkinson's disease. Brain. 2007; 130:1577-1585. [PubMed: 17470494]

Frucht S, Rogers JD, Greene PE, Gordon MF, Fahn S. Falling asleep at the wheel: motor vehicle mishaps in persons taking pramipexole and ropinirole. Neurology. 1999; 52:1908-1910. [PubMed: 10371546]

Fukutake T, Shinotoh H, Nishino H, Ichikawa Y, Goto J, Kanazawa I, Hattori T. Homozygous Machado-Joseph disease presenting as REM sleep behaviour disorder and prominent psychiatric symptoms. Eur J Neurol. 2002; 9:97-100. [PubMed: 11784384]

Gagnon JF, Bedard MA, Fantini ML, Petit D, Panisset M, Rompre S, Carrier J, Montplaisir J. REM sleep behavior disorder and REM sleep without atonia in Parkinson's disease. Neurology. 2002; 59:585-589. [PubMed: 12196654]

Gao J, Huang X, Park Y, Hollenbeck A, Blair A, Schatzkin A, Chen H. Daytime napping, nighttime sleeping, and Parkinson disease. Am J Epidemiol. 2011; 173:1032-1038. [PubMed: 21402730]

Gao X, Schwarzschild MA, O'Reilly EJ, Wang H, Ascherio A. Restless legs syndrome and Parkinson's disease in men. Mov Disord. 2010; 25:2654-2657. [PubMed: 20737545]

Garcia-Borreguero D, Egatz R, Winkelmann J, Berger K. Epidemiology of restless legs syndrome: the current status. Sleep Med Rev. 2006; 10:153-167. [PubMed: 16762806] 
Garcia-Borreguero D, Larrosa O, Bravo M. Parkinson's disease and sleep. Sleep Med Rev. 2003; 7:115-129. [PubMed: 12628213]

Garfinkel D, Laudon M, Zisapel N. Improvement of sleep quality by controlled-release melatonin in benzodiazepine-treated elderly insomniacs. Arch Gerontol Geriatr. 1997; 24:223-231. [PubMed: 15374128]

Gjerstad MD, Aarsland D, Larsen JP. Development of daytime somnolence over time in Parkinson's disease. Neurology. 2002; 58:1544-1546. [PubMed: 12034797]

Godau J, Schweitzer KJ, Liepelt I, Gerloff C, Berg D. Substantia nigra hypoechogenicity: definition and findings in restless legs syndrome. Mov Disord. 2007; 22:187-192. [PubMed: 17133515]

Golombek DA, Rosenstein RE. Physiology of circadian entrainment. Physiol Rev. 2010; 90:10631102. [PubMed: 20664079]

Gonzalez MM, Aston-Jones G. Light deprivation damages monoamine neurons and produces a depressive behavioral phenotype in rats. Proc Natl Acad Sci U S A. 2008; 105:4898-4903. [PubMed: 18347342]

Gravotta L, Gavrila AM, Hood S, Amir S. Global depletion of dopamine using intracerebroventricular 6-hydroxydopamine injection disrupts normal circadian wheel-running patterns and PERIOD2 expression in the rat forebrain. J Mol Neurosci. 2011; 45:162-171. [PubMed: 21484443]

Gruner JA, Marcy VR, Lin YG, Bozyczko-Coyne D, Marino MJ, Gasior M. The roles of dopamine transport inhibition and dopamine release facilitation in wake enhancement and rebound hypersomnolence induced by dopaminergic agents. Sleep. 2009; 32:1425-1438. [PubMed: 19928382]

Hampp G, Albrecht U. The circadian clock and mood-related behavior. Commun Integr Biol. 2008; 1:1-3. [PubMed: 19704445]

Hampp G, Ripperger JA, Houben T, Schmutz I, Blex C, Perreau-Lenz S, Brunk I, Spanagel R, AhnertHilger G, Meijer JH, Albrecht U. Regulation of monoamine oxidase A by circadian-clock components implies clock influence on mood. Curr Biol. 2008; 18:678-683. [PubMed: 18439826]

Happe S, Schrodl B, Faltl M, Muller C, Auff E, Zeitlhofer J. Sleep disorders and depression in patients with Parkinson's disease. Acta Neurol Scand. 2001; 104:275-280. [PubMed: 11696021]

Harper DG, Volicer L, Stopa EG, McKee AC, Nitta M, Satlin A. Disturbance of endogenous circadian rhythm in aging and Alzheimer disease. Am J Geriatr Psychiatry. 2005; 13:359-368. [PubMed: 15879584]

Harrell LE, Balagura S. The effects of dark and light on the functional recovery following lateral hypothalamic lesions. Life Sci. 1974; 15:2079-2087. [PubMed: 4621005]

Hartmann A, Veldhuis JD, Deuschle M, Standhardt H, Heuser I. Twenty-four hour cortisol release profiles in patients with Alzheimer's and Parkinson's disease compared to normal controls: ultradian secretory pulsatility and diurnal variation. Neurobiol Aging. 1997; 18:285-289. [PubMed: 9263193]

Hirsh J, Riemensperger T, Coulom H, Iche M, Coupar J, Birman S. Roles of dopamine in circadian rhythmicity and extreme light sensitivity of circadian entrainment. Curr Biol. 2010; 20:209-214. [PubMed: 20096587]

Hjort N, Ostergaard K, Dupont E. Improvement of sleep quality in patients with advanced Parkinson's disease treated with deep brain stimulation of the subthalamic nucleus. Mov Disord. 2004; 19:196-199. [PubMed: 14978676]

Hobson DE, Lang AE, Martin WR, Razmy A, Rivest J, Fleming J. Excessive daytime sleepiness and sudden-onset sleep in Parkinson disease: a survey by the Canadian Movement Disorders Group. Jama. 2002; 287:455-463. [PubMed: 11798367]

Hofman MA. The human circadian clock and aging. Chronobiol Int. 2000; 17:245-259. [PubMed: 10841206]

Hogl B, Saletu M, Brandauer E, Glatzl S, Frauscher B, Seppi K, Ulmer H, Wenning G, Poewe W. Modafinil for the treatment of daytime sleepiness in Parkinson's disease: a double-blind, randomized, crossover, placebo-controlled polygraphic trial. Sleep. 2002; 25:905-909. [PubMed: 12489899]

Hood S, Cassidy P, Cossette MP, Weigl Y, Verwey M, Robinson B, Stewart J, Amir S. Endogenous dopamine regulates the rhythm of expression of the clock protein PER2 in the rat dorsal striatum 
via daily activation of D2 dopamine receptors. J Neurosci. 2010; 30:14046-14058. [PubMed: 20962226]

Imbesi M, Yildiz S, Dirim Arslan A, Sharma R, Manev H, Uz T. Dopamine receptor-mediated regulation of neuronal "clock" gene expression. Neuroscience. 2009; 158:537-544. [PubMed: 19017537]

Iranzo A, Santamaria J, Rye DB, Valldeoriola F, Marti MJ, Munoz E, Vilaseca I, Tolosa E. Characteristics of idiopathic REM sleep behavior disorder and that associated with MSA and PD. Neurology. 2005; 65:247-252. [PubMed: 16043794]

Iranzo A, Santamaria J, Tolosa E. The clinical and pathophysiological relevance of REM sleep behavior disorder in neurodegenerative diseases. Sleep Med Rev. 2009

Isaac SO, Berridge CW. Wake-promoting actions of dopamine D1 and D2 receptor stimulation. J Pharmacol Exp Ther. 2003; 307:386-394. [PubMed: 12944496]

Ishida Y, Yokoyama C, Inatomi T, Yagita K, Dong X, Yan L, Yamaguchi S, Nagatsu I, Komori T, Kitahama K, Okamura H. Circadian rhythm of aromatic L-amino acid decarboxylase in the rat suprachiasmatic nucleus: gene expression and decarboxylating activity in clock oscillating cells. Genes Cells. 2002; 7:447-459. [PubMed: 12047348]

Jackson CR, Chaurasia SS, Hwang CK, Iuvone PM. Dopamine D receptor activation controls circadian timing of the adenylyl cyclase 1/cyclic AMP signaling system in mouse retina. Eur $\mathbf{J}$ Neurosci. 2011; 34:57-64. [PubMed: 21676039]

Jackson CR, Chaurasia SS, Hwang CK, Iuvone PM. Dopamine D(4) receptor activation controls circadian timing of the adenylyl cyclase 1/cyclic AMP signaling system in mouse retina. Eur J Neurosci. 2011; 34:57-64. [PubMed: 21676039]

Jellinger KA. Alpha-synuclein pathology in Parkinson's and Alzheimer's disease brain: incidence and topographic distribution--a pilot study. Acta Neuropathol (Berl). 2003; 106:191-201. [PubMed: 12845452]

Kafka MS, Benedito MA, Roth RH, Steele LK, Wolfe WW, Catravas GN. Circadian rhythms in catecholamine metabolites and cyclic nucleotide production. Chronobiol Int. 1986; 3:101-115. [PubMed: 2824067]

Kallio M, Haapaniemi T, Turkka J, Suominen K, Tolonen U, Sotaniemi K, Heikkila VP, Myllyla V. Heart rate variability in patients with untreated Parkinson's disease. Eur J Neurol. 2000; 7:667672. [PubMed: 11136353]

Karlsen KH, Larsen JP, Tandberg E, Maeland JG. Influence of clinical and demographic variables on quality of life in patients with Parkinson's disease. J Neurol Neurosurg Psychiatry. 1999; 66:431-435. [PubMed: 10201412]

Kaynak D, Kiziltan G, Kaynak H, Benbir G, Uysal O. Sleep and sleepiness in patients with Parkinson's disease before and after dopaminergic treatment. Eur J Neurol. 2005; 12:199-207. [PubMed: 15693809]

Khaldy H, Leon J, Escames G, Bikjdaouene L, Garcia JJ, Acuna-Castroviejo D. Circadian rhythms of dopamine and dihydroxyphenyl acetic acid in the mouse striatum: effects of pinealectomy and of melatonin treatment. Neuroendocrinology. 2002; 75:201-208. [PubMed: 11914592]

Kimura K, Tachibana N, Kohyama J, Otsuka Y, Fukazawa S, Waki R. A discrete pontine ischemic lesion could cause REM sleep behavior disorder. Neurology. 2000; 55:894-895. [PubMed: 10994023]

King SA. Pain in depression and Parkinson's disease. Am J Psychiatry. 1993; 150:353-354. [PubMed: 8422101]

Korner Y, Meindorfner C, Moller JC, Stiasny-Kolster K, Haja D, Cassel W, Oertel WH, Kruger HP. Predictors of sudden onset of sleep in Parkinson's disease. Mov Disord. 2004; 19:1298-1305. [PubMed: 15389999]

Krishnan PR, Bhatia M, Behari M. Restless legs syndrome in Parkinson's disease: a case-controlled study. Mov Disord. 2003; 18:181-185. [PubMed: 12539212]

Kudo T, Loh DH, Truong D, Wu Y, Colwell CS. Circadian dysfunction in a mouse model of Parkinson's disease. Exp Neurol. 2011; 232:66-75. [PubMed: 21864527]

Kumar S, Bhatia M, Behari M. Sleep disorders in Parkinson's disease. Mov Disord. 2002; 17:775-781. [PubMed: 12210875] 
Kunz D, Bes F. Melatonin as a therapy in REM sleep behavior disorder patients: an open-labeled pilot study on the possible influence of melatonin on REM-sleep regulation. Mov Disord. 1999; 14:507-511. [PubMed: 10348479]

Laloux C, Derambure P, Houdayer E, Jacquesson JM, Bordet R, Destee A, Monaca C. Effect of dopaminergic substances on sleep/wakefulness in saline- and MPTP-treated mice. J Sleep Res. 2008; 17:101-110. [PubMed: 18275560]

Lees AJ, Blackburn NA, Campbell VL. The nighttime problems of Parkinson's disease. Clin Neuropharmacol. 1988; 11:512-519. [PubMed: 3233589]

Lima MM, Andersen ML, Reksidler AB, Vital MA, Tufik S. The role of the substantia nigra pars compacta in regulating sleep patterns in rats. PLoS One. 2007; 2:e513. [PubMed: 17551593]

Lugaresi E, Coccagna G, Gambi D, Berti Ceroni G, Poppi M. Symonds' nocturnal myoclonus. Electroencephalogr Clin Neurophysiol. 1967; 23:289. [PubMed: 4167957]

MacFarlane JG, Cleghorn JM, Brown GM, Streiner DL. The effects of exogenous melatonin on the total sleep time and daytime alertness of chronic insomniacs: a preliminary study. Biol Psychiatry. 1991; 30:371-376. [PubMed: 1912128]

Mahowald, MW.; Schenck, CH. REM Sleep Parasomnias, Principles and practice of sleep medicine. Elsevier Sounders; Philadelphia: 2005. p. 897-916.

Manni R, Terzaghi M, Sartori I, Mancini F, Pacchetti C. Dopamine agonists and sleepiness in PD: review of the literature and personal findings. Sleep Med. 2004; 5:189-193. [PubMed: 15033142]

Maria B, Sophia S, Michalis M, Charalampos L, Andreas P, John ME, Nikolaos SM. Sleep breathing disorders in patients with idiopathic Parkinson's disease. Respir Med. 2003; 97:1151-1157. [PubMed: 14561023]

Marinus J, Visser M, van Hilten JJ, Lammers GJ, Stiggelbout AM. Assessment of sleep and sleepiness in Parkinson disease. Sleep. 2003; 26:1049-1054. [PubMed: 14746389]

Matzuk MM, Saper CB. Preservation of hypothalamic dopaminergic neurons in Parkinson's disease. Ann Neurol. 1985; 18:552-555. [PubMed: 4073850]

McClung CA. Circadian rhythms, the mesolimbic dopaminergic circuit, and drug addiction. ScientificWorldJournal. 2007; 7:194-202. [PubMed: 17982593]

McClung CA, Sidiropoulou K, Vitaterna M, Takahashi JS, White FJ, Cooper DC, Nestler EJ. Regulation of dopaminergic transmission and cocaine reward by the Clock gene. Proc Natl Acad Sci U S A. 2005; 102:9377-9381. [PubMed: 15967985]

Mehta SH, Morgan JC, Sethi KD. Sleep disorders associated with Parkinson's disease: role of dopamine, epidemiology, and clinical scales of assessment. CNS Spectr. 2008; 13:6-11. [PubMed: 18323761]

Mendoza J, Clesse D, Pevet P, Challet E. Food-reward signalling in the suprachiasmatic clock. J Neurochem. 2010; 112:1489-1499. [PubMed: 20067576]

Mihci E, Kardelen F, Dora B, Balkan S. Orthostatic heart rate variability analysis in idiopathic Parkinson's disease. Acta Neurol Scand. 2006; 113:288-293. [PubMed: 16629763]

Monaca C, Laloux C, Jacquesson JM, Gele P, Marechal X, Bordet R, Destee A, Derambure P. Vigilance states in a parkinsonian model, the MPTP mouse. Eur J Neurosci. 2004; 20:24742478. [PubMed: 15525288]

Montastruc JL, Brefel-Courbon C, Senard JM, Bagheri H, Ferreira J, Rascol O, Lapeyre-Mestre M. Sleep attacks and antiparkinsonian drugs: a pilot prospective pharmacoepidemiologic study. Clin Neuropharmacol. 2001; 24:181-183. [PubMed: 11391132]

Monti JM, Hawkins M, Jantos H, D’Angelo L, Fernandez M. Biphasic effects of dopamine D-2 receptor agonists on sleep and wakefulness in the rat. Psychopharmacology (Berl). 1988; 95:395400. [PubMed: 3137628]

Monti JM, Jantos H. The roles of dopamine and serotonin, and of their receptors, in regulating sleep and waking. Prog Brain Res. 2008; 172:625-646. [PubMed: 18772053]

Monti JM, Monti D. The involvement of dopamine in the modulation of sleep and waking. Sleep Med Rev. 2007; 11:113-133. [PubMed: 17275369] 
Murillo-Rodriguez E, Arias-Carrion O, Sanguino-Rodriguez K, Gonzalez-Arias M, Haro R. Mechanisms of sleep-wake cycle modulation. CNS Neurol Disord Drug Targets. 2009; 8:245253. [PubMed: 19689306]

Nomura T, Inoue Y, Miyake M, Yasui K, Nakashima K. Prevalence and clinical characteristics of restless legs syndrome in Japanese patients with Parkinson's disease. Mov Disord. 2006; 21:380384. [PubMed: 16211604]

Norlinah MI, Afidah KN, Noradina AT, Shamsul AS, Hamidon BB, Sahathevan R, Raymond AA. Sleep disturbances in Malaysian patients with Parkinson's disease using polysomnography and PDSS. Parkinsonism Relat Disord. 2009; 15:670-674. [PubMed: 19362875]

Nutt JG, Woodward WR, Carter JH, Trotman TL. Influence of fluctuations of plasma large neutral amino acids with normal diets on the clinical response to levodopa. J Neurol Neurosurg Psychiatry. 1989; 52:481-487. [PubMed: 2738591]

Ohayon MM, Caulet M, Priest RG. Violent behavior during sleep. J Clin Psychiatry. 1997; 58:369376. quiz 377. [PubMed: 9515980]

Olson EJ, Boeve BF, Silber MH. Rapid eye movement sleep behaviour disorder: demographic, clinical and laboratory findings in 93 cases. Brain. 2000; 123 (Pt 2):331-339. [PubMed: 10648440]

Ondo WG, Dat Vuong K, Khan H, Atassi F, Kwak C, Jankovic J. Daytime sleepiness and other sleep disorders in Parkinson's disease. Neurology. 2001; 57:1392-1396. [PubMed: 11673578]

Ondo WG, Fayle R, Atassi F, Jankovic J. Modafinil for daytime somnolence in Parkinson's disease: double blind, placebo controlled parallel trial. J Neurol Neurosurg Psychiatry. 2005; 76:16361639. [PubMed: 16291885]

Ondo WG, Vuong KD, Jankovic J. Exploring the relationship between Parkinson disease and restless legs syndrome. Arch Neurol. 2002; 59:421-424. [PubMed: 11890847]

Ozekmekci S, Apaydin H, Kilic E. Clinical features of 35 patients with Parkinson's disease displaying REM behavior disorder. Clin Neurol Neurosurg. 2005; 107:306-309. [PubMed: 15885389]

Pacchetti C, Manni R, Zangaglia R, Mancini F, Marchioni E, Tassorelli C, Terzaghi M, Ossola M, Martignoni E, Moglia A, Nappi G. Relationship between hallucinations, delusions, and rapid eye movement sleep behavior disorder in Parkinson's disease. Mov Disord. 2005; 20:1439-1448. [PubMed: 16028215]

Pahwa R, Busenbark K, Huber SJ, Michalek D, Hubble JP, Koller WC. Clinical experience with controlled-release carbidopa/levodopa in Parkinson's disease. Neurology. 1993; 43:677-681. [PubMed: 8469321]

Pastor P, Tolosa E. Cabergoline in the treatment of Parkinson's disease. Neurologia. 2003; 18:202209. [PubMed: 12721865]

Pathak A, Senard JM. Blood pressure disorders during Parkinson's disease: epidemiology, pathophysiology and management. Expert Rev Neurother. 2006; 6:1173-1180. [PubMed: 16893345]

Paus S, Brecht HM, Koster J, Seeger G, Klockgether T, Wullner U. Sleep attacks, daytime sleepiness, and dopamine agonists in Parkinson's disease. Mov Disord. 2003; 18:659-667. [PubMed: 12784269]

Paus S, Schmitz-Hubsch T, Wullner U, Vogel A, Klockgether T, Abele M. Bright light therapy in Parkinson's disease: a pilot study. Mov Disord. 2007; 22:1495-1498. [PubMed: 17516492]

Piccini P, Del Dotto P, Pardini C, D’Antonio P, Rossi G, Bonuccelli U. Diurnal worsening in Parkinson patients treated with levodopa. Riv Neurol. 1991; 61:219-224. [PubMed: 1813974]

Pierangeli G, Provini F, Maltoni P, Barletta G, Contin M, Lugaresi E, Montagna P, Cortelli P. Nocturnal body core temperature falls in Parkinson's disease but not in Multiple-System Atrophy. Mov Disord. 2001; 16:226-232. [PubMed: 11295774]

Placidi F, Izzi F, Romigi A, Stanzione P, Marciani MG, Brusa L, Sperli F, Galati S, Pasqualetti P, Pierantozzi M. Sleep-wake cycle and effects of cabergoline monotherapy in de novo Parkinson's disease patients. An ambulatory polysomnographic study. J Neurol. 2008; 255:1032-1037. [PubMed: 18500498]

Plaschke M, Trenkwalder P, Dahlheim H, Lechner C, Trenkwalder C. Twenty-four-hour blood pressure profile and blood pressure responses to head-up tilt tests in Parkinson's disease and multiple system atrophy. J Hypertens. 1998; 16:1433-1441. [PubMed: 9814613] 
Plazzi G, Corsini R, Provini F, Pierangeli G, Martinelli P, Montagna P, Lugaresi E, Cortelli P. REM sleep behavior disorders in multiple system atrophy. Neurology. 1997; 48:1094-1097. [PubMed: 9109907]

Poewe W, Hogl B. Akathisia, restless legs and periodic limb movements in sleep in Parkinson's disease. Neurology. 2004; 63:S12-16. [PubMed: 15505135]

Porter B, Macfarlane R, Walker R. The frequency and nature of sleep disorders in a community-based population of patients with Parkinson's disease. Eur J Neurol. 2008; 15:50-54. [PubMed: 18042241]

Postuma RB, Gagnon JF, Vendette M, Charland K, Montplaisir J. REM sleep behaviour disorder in Parkinson's disease is associated with specific motor features. J Neurol Neurosurg Psychiatry. 2008; 79:1117-1121. [PubMed: 18682443]

Postuma RB, Gagnon JF, Vendette M, Fantini ML, Massicotte-Marquez J, Montplaisir J. Quantifying the risk of neurodegenerative disease in idiopathic REM sleep behavior disorder. Neurology. 2009; 72:1296-1300. [PubMed: 19109537]

PSG. Pramipexole vs levodopa as initial treatment for Parkinson disease: A randomized controlled trial. JAMA. 2000; 284:1931-1938. [PubMed: 11035889]

Pungor K, Papp M, Kekesi K, Juhasz G. A novel effect of MPTP: the selective suppression of paradoxical sleep in cats. Brain Res. 1990; 525:310-314. [PubMed: 2253031]

Pursiainen V, Haapaniemi TH, Korpelainen JT, Huikuri HV, Sotaniemi KA, Myllyla VV. Circadian heart rate variability in Parkinson's disease. J Neurol. 2002; 249:1535-1540. [PubMed: 12420094]

Qu WM, Huang ZL, Xu XH, Matsumoto N, Urade Y. Dopaminergic D1 and D2 receptors are essential for the arousal effect of modafinil. J Neurosci. 2008; 28:8462-8469. [PubMed: 18716204]

Qu WM, Xu XH, Yan MM, Wang YQ, Urade Y, Huang ZL. Essential role of dopamine D2 receptor in the maintenance of wakefulness, but not in homeostatic regulation of sleep, in mice. J Neurosci. 2010; 30:4382-4389. [PubMed: 20335474]

Rascol O, Brooks DJ, Korczyn AD, De Deyn PP, Clarke CE, Lang AE. A five-year study of the incidence of dyskinesia in patients with early Parkinson's disease who were treated with ropinirole or levodopa. 056 Study Group. N Engl J Med. 2000; 342:1484-1491. [PubMed: 10816186]

Reinberg A, Ashkenazi I. Internal desynchronization of circadian rhythms and tolerance to shift work. Chronobiol Int. 2008; 25:625-643. [PubMed: 18622820]

Reinberg A, Proux S, Bartal JP, Levi F, Bicakova-Rocher A. Circadian rhythms in competitive sabre fencers: internal desynchronization and performance. Chronobiol Int. 1985; 2:195-201. [PubMed: 3870850]

Ringman JM, Simmons JH. Treatment of REM sleep behavior disorder with donepezil: a report of three cases. Neurology. 2000; 55:870-871. [PubMed: 10994012]

Roth T, Rye DB, Borchert LD, Bartlett C, Bliwise DL, Cantor C, Gorell JM, Hubble JP, Musch B, Olanow CW, Pollak C, Stern MB, Watts RL. Assessment of sleepiness and unintended sleep in Parkinson's disease patients taking dopamine agonists. Sleep Med. 2003; 4:275-280. [PubMed: 14592299]

Roybal K, Theobold D, Graham A, DiNieri JA, Russo SJ, Krishnan V, Chakravarty S, Peevey J, Oehrlein N, Birnbaum S, Vitaterna MH, Orsulak P, Takahashi JS, Nestler EJ, Carlezon WA Jr, McClung CA. Mania-like behavior induced by disruption of CLOCK. Proc Natl Acad Sci U S A. 2007; 104:6406-6411. [PubMed: 17379666]

Ruan GX, Allen GC, Yamazaki S, McMahon DG. An autonomous circadian clock in the inner mouse retina regulated by dopamine and GABA. PLoS Biol. 2008; 6:e249. [PubMed: 18959477]

Ruottinen HM, Partinen M, Hublin C, Bergman J, Haaparanta M, Solin O, Rinne JO. An FDOPA PET study in patients with periodic limb movement disorder and restless legs syndrome. Neurology. 2000; 54:502-504. [PubMed: 10668725]

Rye D. Seeing beyond one's nose: sleep disruption and excessive sleepiness accompany motor disability in the MPTP treated primate. Exp Neurol. 2010; 222:179-180. [PubMed: 20064510]

Rye DB. Parkinson's disease and RLS: the dopaminergic bridge. Sleep Med. 2004; 5:317-328. [PubMed: 15165542] 
Rye DB. The two faces of Eve: dopamine's modulation of wakefulness and sleep. Neurology. 2004; 63:S2-7. [PubMed: 15505137]

Rye DB, Bliwise DL, Dihenia B, Gurecki P. FAST TRACK: daytime sleepiness in Parkinson's disease. J Sleep Res. 2000; 9:63-69. [PubMed: 10733691]

Sakamoto K, Liu C, Kasamatsu M, Pozdeyev NV, Iuvone PM, Tosini G. Dopamine regulates melanopsin mRNA expression in intrinsically photosensitive retinal ganglion cells. Eur J Neurosci. 2005; 22:3129-3136. [PubMed: 16367779]

Scaglione C, Vignatelli L, Plazzi G, Marchese R, Negrotti A, Rizzo G, Lopane G, Bassein L, Maestri M, Bernardini S, Martinelli P, Abbruzzese G, Calzetti S, Bonuccelli U, Provini F, Coccagna G. REM sleep behaviour disorder in Parkinson's disease: a questionnaire-based study. Neurol Sci. 2005; 25:316-321. [PubMed: 15729494]

Schafer H, Pauleit D, Sudhop T, Gouni-Berthold I, Ewig S, Berthold HK. Body fat distribution, serum leptin, and cardiovascular risk factors in men with obstructive sleep apnea. Chest. 2002; 122:829-839. [PubMed: 12226021]

Schenck CH, Bundlie SR, Ettinger MG, Mahowald MW. Chronic behavioral disorders of human REM sleep: a new category of parasomnia. Sleep. 1986; 9:293-308. [PubMed: 3505730]

Schenck CH, Bundlie SR, Mahowald MW. Delayed emergence of a parkinsonian disorder in $38 \%$ of 29 older men initially diagnosed with idiopathic rapid eye movement sleep behaviour disorder. Neurology. 1996; 46:388-393. [PubMed: 8614500]

Schenck CH, Mahowald MW. Motor dyscontrol in narcolepsy: rapid-eye-movement (REM) sleep without atonia and REM sleep behavior disorder. Ann Neurol. 1992; 32:3-10. [PubMed: 1642469]

Schenck CH, Mahowald MW. REM sleep behavior disorder: clinical, developmental, and neuroscience perspectives 16 years after its formal identification in SLEEP. Sleep. 2002; 25:120138. [PubMed: 11902423]

Schenck CH, Mahowald MW. Rapid eye movement sleep parasomnias. Neurol Clin. 2005; 23:11071126. [PubMed: 16243618]

Schenck CH, Mahowald MW, Anderson ML, Silber MH, Boeve BF, Parisi JE. Lewy body variant of Alzheimer's disease (AD) identified by postmortem ubiquitin staining in a previously reported case of AD associated with REM sleep behavior disorder. Biol Psychiatry. 1997; 42:527-528. [PubMed: 9285091]

Schmidauer C, Sojer M, Seppi K, Stockner H, Hogl B, Biedermann B, Brandauer E, Peralta CM, Wenning GK, Poewe W. Transcranial ultrasound shows nigral hypoechogenicity in restless legs syndrome. Ann Neurol. 2005; 58:630-634. [PubMed: 16037973]

Senard JM, Chamontin B, Rascol A, Montastruc JL. Ambulatory blood pressure in patients with Parkinson's disease without and with orthostatic hypotension. Clin Auton Res. 1992; 2:99-104. [PubMed: 1638111]

Shang Y, Haynes P, Pirez N, Harrington KI, Guo F, Pollack J, Hong P, Griffith LC, Rosbash M. Imaging analysis of clock neurons reveals light buffers the wake-promoting effect of dopamine. Nat Neurosci. 2011; 14:889-895. [PubMed: 21685918]

Shirani A, St Louis EK. Illuminating rationale and uses for light therapy. J Clin Sleep Med. 2009; 5:155-163. [PubMed: 19968050]

Shulman LM, Taback RL, Bean J, Weiner WJ. Comorbidity of the nonmotor symptoms of Parkinson's disease. Mov Disord. 2001; 16:507-510. [PubMed: 11391746]

Silva EJ, Wang W, Ronda JM, Wyatt JK, Duffy JF. Circadian and wake-dependent influences on subjective sleepiness, cognitive throughput, and reaction time performance in older and young adults. Sleep. 2010; 33:481-490. [PubMed: 20394317]

Sixel-Doring F, Trautmann E, Mollenhauer B, Trenkwalder C. Associated factors for REM sleep behavior disorder in Parkinson disease. Neurology. 2011; 77:1048-1054. [PubMed: 21832215]

Sleipness EP, Sorg BA, Jansen HT. Contribution of the suprachiasmatic nucleus to day:night variation in cocaine-seeking behavior. Physiol Behav. 2007; 91:523-530. [PubMed: 17573077]

Sleipness EP, Sorg BA, Jansen HT. Diurnal differences in dopamine transporter and tyrosine hydroxylase levels in rat brain: dependence on the suprachiasmatic nucleus. Brain Res. 2007; 1129:34-42. [PubMed: 17156761] 
Stevens S, Cormella CL, Stepanski EJ. Daytime sleepiness and alertness in patients with Parkinson disease. Sleep. 2004; 27:967-972. [PubMed: 15453556]

Strieder DJ, Baker WG, Baringer JR, Kazemi H. Chronic hypoventilation of central origin. A case with encephalitis lethargica and Parkinson's syndrome. Am Rev Respir Dis. 1967; 96:501-507. [PubMed: 6039103]

Struck LK, Rodnitzky RL, Dobson JK. Circadian fluctuations of contrast sensitivity in Parkinson's disease. Neurology. 1990; 40:467-470. [PubMed: 2314590]

Suzuki K, Miyamoto T, Miyamoto M, Kaji Y, Takekawa H, Hirata K. Circadian variation of core body temperature in Parkinson disease patients with depression: a potential biological marker for depression in Parkinson disease. Neuropsychobiology. 2007; 56:172-179. [PubMed: 18332645]

Syed BH, Rye DB, Singh G. REM sleep behavior disorder and SCA-3 (Machado-Joseph disease). Neurology. 2003; 60:148. [PubMed: 12525744]

Tachibana N, Kimura K, Kitajima K, Shinde A, Kimura J, Shibasaki H. REM sleep motor dysfunction in multiple system atrophy: with special emphasis on sleep talk as its early clinical manifestation. J Neurol Neurosurg Psychiatry. 1997; 63:678-681. [PubMed: 9408115]

Tan EK, Lum SY, Wong MC. Restless legs syndrome in Parkinson's disease. J Neurol Sci. 2002; 196:33-36. [PubMed: 11959153]

Tandberg E, Larsen JP, Karlsen K. A community-based study of sleep disorders in patients with Parkinson's disease. Mov Disord. 1998; 13:895-899. [PubMed: 9827612]

Thannickal TC, Lai YY, Siegel JM. Hypocretin (orexin) cell loss in Parkinson's disease. Brain. 2007; 130:1586-1595. [PubMed: 17491094]

Touitou Y, Haus E. Alterations with aging of the endocrine and neuroendocrine circadian system in humans. Chronobiol Int. 2000; 17:369-390. [PubMed: 10841211]

Trenkwalder C, Kohnen R, Hogl B, Metta V, Sixel-Doring F, Frauscher B, Hulsmann J, MartinezMartin P, Chaudhuri KR. Parkinson's disease sleep scale--validation of the revised version PDSS-2. Mov Disord. 2011; 26:644-652. [PubMed: 21312275]

Trotti LM, Bliwise DL. No increased risk of obstructive sleep apnea in Parkinson's disease. Mov Disord. 2010; 25:2246-2249. [PubMed: 20669289]

Turek FW, Penev P, Zhang Y, van Reeth O, Zee P. Effects of age on the circadian system. Neurosci Biobehav Rev. 1995; 19:53-58. [PubMed: 7770197]

Turjanski N, Lees AJ, Brooks DJ. Striatal dopaminergic function in restless legs syndrome: 18F-dopa and 11C-raclopride PET studies. Neurology. 1999; 52:932-937. [PubMed: 10102408]

Turner WA, Critchley M. Respiratory disorders in epidemic encephalitis. Brain. 1925; 48:72-104.

van Coevorden A, Mockel J, Laurent E, Kerkhofs M, L'Hermite-Baleriaux M, Decoster C, Neve P, Van Cauter E. Neuroendocrine rhythms and sleep in aging men. Am J Physiol. 1991; 260:E651661. [PubMed: 2018128]

van den Heuvel CJ, Lushington K. Chronobiology and insomnia: pathophysiology and treatment of circadian rhythm sleep disorders. Expert Rev Neurother. 2002; 2:249-260. [PubMed: 19811006]

Van den Kerchove M, Jacquy J, Gonce M, De Deyn PP. Sustained-release levodopa in parkinsonian patients with nocturnal disabilities. Acta Neurol Belg. 1993; 93:32-39. [PubMed: 8451915]

van Hilten B, Hoff JI, Middelkoop HA, van der Velde EA, Kerkhof GA, Wauquier A, Kamphuisen HA, Roos RA. Sleep disruption in Parkinson's disease. Assessment by continuous activity monitoring. Arch Neurol. 1994; 51:922-928. [PubMed: 8080393]

van Hilten JJ, Hoogland G, van der Velde EA, Middelkoop HA, Kerkhof GA, Roos RA. Diurnal effects of motor activity and fatigue in Parkinson's disease. J Neurol Neurosurg Psychiatry. 1993; 56:874-877. [PubMed: 8350103]

van Hilten JJ, Kabel JF, Middelkoop HA, Kramer CG, Kerkhof GA, Roos RA. Assessment of response fluctuations in Parkinson's disease by ambulatory wrist activity monitoring. Acta Neurol Scand. 1993; 87:171-177. [PubMed: 8475685]

van Hilten JJ, Middelkoop HA, Kerkhof GA, Roos RA. A new approach in the assessment of motor activity in Parkinson's disease. J Neurol Neurosurg Psychiatry. 1991; 54:976-979. [PubMed: 1800670] 
van Hilten JJ, Weggeman M, van der Velde EA, Kerkhof GA, van Dijk JG, Roos RA. Sleep, excessive daytime sleepiness and fatigue in Parkinson's disease. J Neural Transm Park Dis Dement Sect. 1993; 5:235-244. [PubMed: 8369103]

van Vliet SA, Vanwersch RA, Jongsma MJ, van der Gugten J, Olivier B, Philippens IH. Neuroprotective effects of modafinil in a marmoset Parkinson model: behavioral and neurochemical aspects. Behav Pharmacol. 2006; 17:453-462. [PubMed: 16940766]

Verbaan D, van Rooden SM, Visser M, Marinus J, van Hilten JJ. Nighttime sleep problems and daytime sleepiness in Parkinson's disease. Mov Disord. 2008; 23:35-41. [PubMed: 17960797]

Verhave PS, Jongsma MJ, Van den Berg RM, Vis JC, Vanwersch RA, Smit AB, Van Someren EJ, Philippens IH. REM sleep behavior disorder in the marmoset MPTP model of early Parkinson disease. Sleep. 2011; 34:1119-1125. [PubMed: 21804674]

Viswanathan N, Weaver DR, Reppert SM, Davis FC. Entrainment of the fetal hamster circadian pacemaker by prenatal injections of the dopamine agonist SKF 38393. J Neurosci. 1994; 14:5393-5398. [PubMed: 7916044]

Viyoch J, Matsunaga N, Yoshida M, To H, Higuchi S, Ohdo S. Effect of haloperidol on mPer1 gene expression in mouse suprachiasmatic nuclei. J Biol Chem. 2005; 280:6309-6315. [PubMed: 15590637]

Volkow ND, Fowler JS, Logan J, Alexoff D, Zhu W, Telang F, Wang GJ, Jayne M, Hooker JM, Wong C, Hubbard B, Carter P, Warner D, King P, Shea C, Xu Y, Muench L, Apelskog-Torres K. Effects of modafinil on dopamine and dopamine transporters in the male human brain: clinical implications. JAMA. 2009; 301:1148-1154. [PubMed: 19293415]

Walters AS, Hening W, Rubinstein M, Chokroverty S. A clinical and polysomnographic comparison of neuroleptic-induced akathisia and the idiopathic restless legs syndrome. Sleep. 1991; 14:339_ 345. [PubMed: 1682986]

Waterhouse J. Circadian rhythms and cognition. Prog Brain Res. 2010; 185:131-153. [PubMed: 21075237]

Weaver DR, Rivkees SA, Reppert SM. D1-dopamine receptors activate c-fos expression in the fetal suprachiasmatic nuclei. Proc Natl Acad Sci U S A. 1992; 89:9201-9204. [PubMed: 1384044]

Webb IC, Baltazar RM, Lehman MN, Coolen LM. Bidirectional interactions between the circadian and reward systems: is restricted food access a unique zeitgeber? Eur J Neurosci. 2009; 30:1739_ 1748. [PubMed: 19878278]

Weber M, Lauterburg T, Tobler I, Burgunder JM. Circadian patterns of neurotransmitter related gene expression in motor regions of the rat brain. Neurosci Lett. 2004; 358:17-20. [PubMed: 15016424]

Wetter TC, Brunner H, Collado-Seidel V, Trenkwalder C, Winkelmann J. Sleep and periodic limb movements in corticobasal degeneration. Sleep Med. 2002; 3:33-36. [PubMed: 14592251]

Wetter TC, Collado-Seidel V, Pollmacher T, Yassouridis A, Trenkwalder C. Sleep and periodic leg movement patterns in drug-free patients with Parkinson's disease and multiple system atrophy. Sleep. 2000; 23:361-367. [PubMed: 10811380]

Whitehead DL, Davies AD, Playfer JR, Turnbull CJ. Circadian rest-activity rhythm is altered in Parkinson's disease patients with hallucinations. Mov Disord. 2008; 23:1137-1145. [PubMed: 18442142]

Willis GL, Turner EJ. Primary and secondary features of Parkinson's disease improve with strategic exposure to bright light: a case series study. Chronobiol Int. 2007; 24:521-537. [PubMed: 17612949]

Wirz-Justice A, Da Prada M, Reme C. Circadian rhythm in rat retinal dopamine. Neurosci Lett. 1984; 45:21-25. [PubMed: 6728302]

Wisor JP, Nishino S, Sora I, Uhl GH, Mignot E, Edgar DM. Dopaminergic role in stimulant-induced wakefulness. J Neurosci. 2001; 21:1787-1794. [PubMed: 11222668]

Witkovsky P. Dopamine and retinal function. Doc Ophthalmol. 2004; 108:17-40. [PubMed: 15104164]

Wulff K, Gatti S, Wettstein JG, Foster RG. Sleep and circadian rhythm disruption in psychiatric and neurodegenerative disease. Nat Rev Neurosci. 2010; 11:589-599. [PubMed: 20631712] 
Young A, Home M, Churchward T, Freezer N, Holmes P, Ho M. Comparison of sleep disturbance in mild versus severe Parkinson's disease. Sleep. 2002; 25:573-577. [PubMed: 12150324]

Zambelis T, Paparrigopoulos T, Soldatos CR. REM sleep behaviour disorder associated with a neurinoma of the left pontocerebellar angle. J Neurol Neurosurg Psychiatry. 2002; 72:821-822. [PubMed: 12023439]

Zisapel N. Melatonin-dopamine interactions: from basic neurochemistry to a clinical setting. Cell Mol Neurobiol. 2001; 21:605-616. [PubMed: 12043836] 


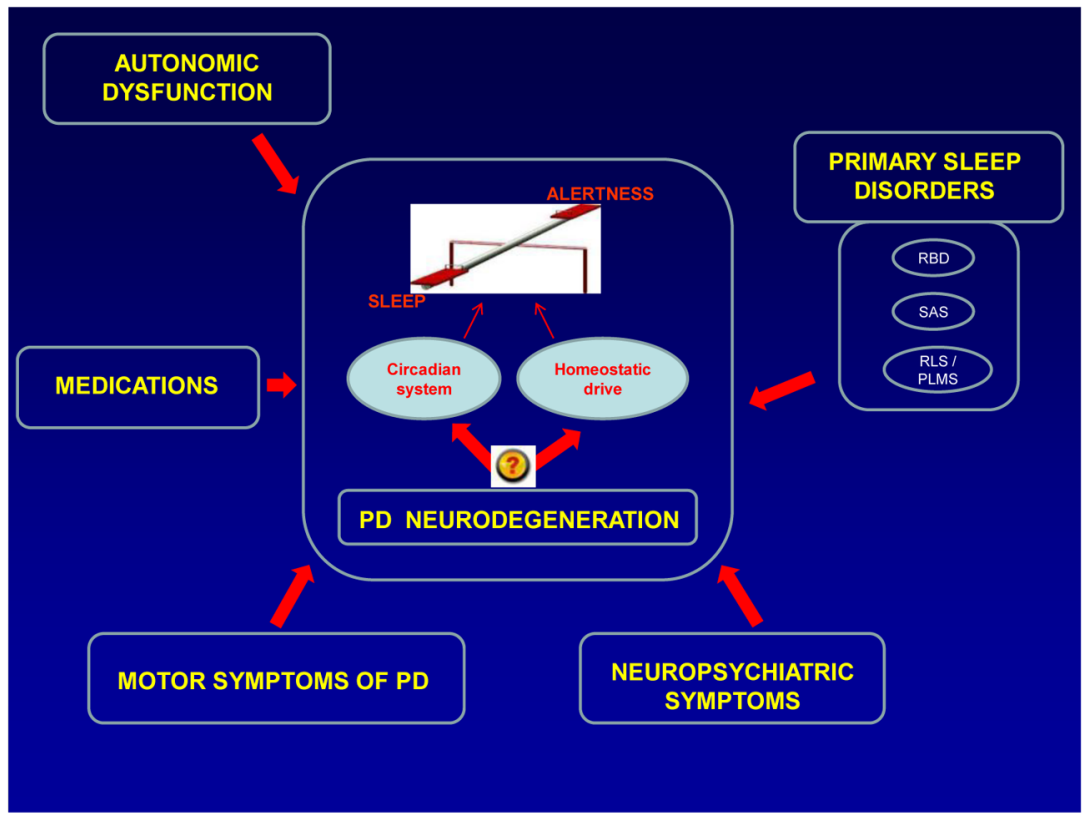

Figure 1.

A proposed model for dysregulation of the sleep-wake cycle in PD. 